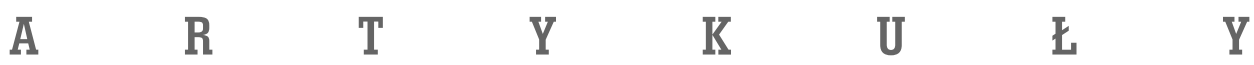

Bogumił Szady

https://orcid.org/0000-0003-0059-5596

Instytut Historii Katolickiego Uniwersytetu Lubelskiego Jana Pawła II

\title{
Rozwój struktur parafialnych i dekanalnych metropolii mohylewskiej (1783-1918)*
}

Zarys treści: Artykuł w układzie chronologicznym przedstawia analizę geograficzno-historyczną rozwoju struktur parafialnych w metropolii mohylewskiej w latach 1783-1918. Główną podstawę źródłową stanowią schematyzmy diecezjalne oraz spisy duchowieństwa. Zmiany sieci parafialnej zostały ukazane $\mathrm{w}$ ramach jednostek administracyjnych wyższego rzędu: dekanatów oraz diecezji (mohylewskiej, wileńskiej, żmudzkiej, łucko-żytomierskiej, kamienieckiej, mińskiej, tyraspolskiej). Tekst podejmuje próbę interpretacji tych zmian przez określenie ich przyczyn i okoliczności.

Outline of content: The article presents, in chronological order, a geographic-historical analysis of the development of parish structures in the Mogilev metropolis in 1783-1918. The analysis has been based on two primary sources: the annual diocesan handbooks called Schematisms and registers of the clergy. The changes in the network of parishes are presented within the territorial administrative units of the higher level: deaneries and dioceses (of Mogilev, Vilnius, Samogitian diocese, and the dioceses of Lutsk and Zhytomyr, Kamianets-Podilskyi, Minsk, and Tiraspol). The paper attempts to interpret these changes by establishing their causes and circumstances.

Słowa kluczowe: Kościół katolicki, metropolia mohylewska, parafie, Rosja, geografia historyczna, schematyzmy diecezjalne

Keywords: Catholic Church, Mogilev metropolis, parishes, Russia, historical geography, diocesan Schematisms

\footnotetext{
* Skrócona wersja niniejszego tekstu ukaże się w najbliższym czasie w języku rosyjskim w opracowaniu zbiorowym poświęconym dziejom Kościoła katolickiego w Rosji w XIX w., redagowanym przez Mariana Radwana oraz Irenę Wodzianowską. Niniejszym składam podziękowanie za wsparcie oraz konsultację merytoryczną udzielone przy prowadzeniu badań i pracy nad tekstem. Dziękuję także Janowi Szczepaniakowi oraz Markowi Hałaburdzie za udostępnienie kopii schematyzów diecezjalnych z XIX w., często trudno dostępnych w polskich zbiorach bibliotecznych i archiwalnych. Podobne podziękowanie jestem winien pracownikom Książnicy Zamojskiej im. Stanisława Kostki Zamoyskiego w Zamościu, którzy na moją prośbę nieodpłatnie wykonali kopie cyfrowe znajdujących się tam schematyzmów diecezji wileńskiej.
} 


\section{Wstęp: okres 1772-1795}

Podstawowe znaczenie dla rozwoju życia społeczno-religijnego w Kościele katolickim miały i mają struktury parafialne. Oprócz duszpasterstwa parafie prowadziły działalność edukacyjną oraz opiekuńczą, a w wyjątkowych okolicznościach wykazywały także szerszą aktywność społeczną, a nawet polityczną. Zorganizowana i stabilna wspólnota parafialna, ze stałą obecnością kapłana oraz kościołem parafialnym, jest świadectwem trwałej obecności Kościoła katolickiego. Jednocześnie sytuacja i położenie kościołów parafialnych odzwierciedla kondycję Kościoła na określonym terytorium.

Do I rozbioru Polski w 1772 r. działalność Kościoła katolickiego w Cesarstwie Rosyjskim miała charakter misyjny. Ludność Rosji była prawie wyłącznie prawosławna. Misje jezuickie w Moskwie i Petersburgu dały początek pierwszym parafiom, które powstały $\mathrm{w}$ tych miastach $\mathrm{w}$ pierwszej połowie XVIII w. Miało to związek z polityką „otwartych drzwi” cara Piotra I oraz ukazem zezwalającym na budowę kościołów katolickich w Imperium Rosyjskim z 1705 r. Ustrój Kościoła katolickiego w Petersburgu, Moskwie, a potem w całym Cesarstwie regulowała początkowo „Ordynacja Kościoła rzymskokatolickiego petersburskiego” z 1769 r., która podporządkowała kościoły katolickie istniejącemu od 1717 r. Justickolegium dla Liwonii, Estonii i Finlandii.

Sytuację Kościoła katolickiego w Rosji zmieniły wydarzenia polityczne z lat 1772-1795. W ich wyniku do Cesarstwa Rosyjskiego zostały włączone wschodnie rubieże Rzeczypospolitej Obojga Narodów posiadające ludność katolicką oraz zorganizowane struktury diecezjalne i parafialne. Legły one u podstaw powołania w 1774 r. tzw. biskupstwa białoruskiego, a następnie metropolii mohylewskiej, która miała obejmować wszystkie kościoły katolickie w Rosji. Metropolia mohylewska od momentu utworzenia w 1783 r. była największą terytorialnie jednostką Kościoła rzymskokatolickiego na świecie. W ciągu XIX stulecia ulegała licznym przeobrażeniom na wszystkich poziomach organizacji terytorialnej - od granic zewnętrznych, przez podział diecezjalny, aż po struktury parafialne i dekanalne. W odróżnieniu od epoki nowożytnej, w okresie rozbiorów przyrastała znacząco liczba źródeł proweniencji państwowej (rządowej), jak też kościelnej, które mogą służyć do badań nad geografią struktur administracyjnych. Biorąc pod uwagę objętość prezentowanego studium, nie może być ono analitycznym i dokładnym omówieniem rozwoju administracyjnego metropolii mohylewskiej na poziomie jednostek podstawowych - parafii i dekanatów. Głównym celem pracy będzie dokonanie przeglądu i krytyki stanu wiedzy oraz głównych źródeł wykorzystywanych w badaniach, co pozwoli na stworzenie syntetycznego obrazu rozwoju administracji Kościoła łacińskiego w Rosji na poziomie najniższych jednostek terytorialnych. Geograficzno-chronologiczna prezentacja struktur parafialnych i dekanalnych metropolii mohylewskiej jest pierwszym krokiem do określenia czynników politycznych, demograficznych (migracje) i społeczno-religijnych, które mogły wpływać na dynamikę i kształt obserwowanych zmian. 
Dzieje metropolii mohylewskiej między 1783 r. a 1798 r. cechują liczne zmiany organizacyjne mające związek $\mathrm{z}$ włączaniem do państwa rosyjskiego kolejnych części dawnego terytorium Rzeczypospolitej. Na obszarze tym funkcjonowały struktury Kościoła łacińskiego, którego diecezje były związane z metropoliami lwowską i gnieźnieńską. To właśnie te struktury, poza wcześniej istniejącymi już w Imperium Rosyjskim nielicznymi kościołami katolickimi obrządku rzymskiego, stanowiły zalążek powołanej w $1783 \mathrm{r}$. archidiecezji i metropolii mohylewskiej (wcześniej tzw. biskupstwa białoruskiego, od 1774 r.). Dokumenty powołujące biskupstwo białoruskie, w tym wyznaczenie na biskupa Stanisława Siestrzeńcewicza, wyraźnie stwierdzały, że nowa diecezja miała obejmować wszystkie kościoły katolickie w Rosji, włącznie $\mathrm{z}$ terenami przyłączonymi w I rozbiorze ${ }^{1}$. Faktycznie jednak biskup mohylewski (białoruski) sprawował jurysdykcję jedynie na ziemiach przyłączonych w wyniku I rozbioru do Rosji. Inne placówki katolickie w Cesarstwie, np. kościoły Petersburga i Moskwy, tak jak wcześniej były podporządkowane Justickolegium protestanckiemu dla Inflant, Estonii i Finlandii².

Dość trudno określić pierwotną sytuację organizacyjną metropolii mohylewskiej. Artykuł Władysława Knapińskiego w Encyklopedii kościelnej wspomina o wykazie przygotowanym przez bpa Siestrzeńcewicza w 1776 r., czyli jeszcze przed oficjalnym powołaniem arcybiskupstwa. Miał on potwierdzać funkcjonowanie 149 parafii zarządzanych głównie przez duchowieństwo zakonne. Pod zarządem kleru świeckiego winno być zaledwie 60 świątyń. Niestety źródło tej informacji nie jest znane ${ }^{3}$. Nie udało się także dotrzeć do schematyzmu archidiecezji mohylewskiej z 1786 r., wzmiankowanego w opracowaniu Augustina Theinera ${ }^{4}$. W swojej relacji złożonej do Rzymu w 1789 r. bp Siestrzeńcewicz wymienia tylko 22 świątynie, które „post praecedentem dictam meam relationem supervenerunt”5.

1 „Quod adtinet [sic!] ejus munus, regimenque Episcopale super Ecclesias tum in Provinciis a Regno Poloniae acquisitis, tum Petropoli, Moscuae, caeterisque Nostri Imperii in Urbibus sitas" (22 listopada / 3 grudnia 1773); „Nos propterea tranquilitati bonoque ordini Ecclesiasticorum RomanoCatholicorum consulentes, aequum esse judicavimus non solum omnes, quae illorum Catholicorum Episcopatuum conficiebant, partes in unam Dioecesim Catholicam redigere, sed et omnes Catholicas, tum in capitibus, tum et aliis Imperii Nostri Urbibus existentes Ecclesias, et in variis longe dissitis locis degentes Romano-Catholicos Sacerdotes illi aggregare" (12/23 maja 1774), Die neuesten Zustände der katholishen Kirche beider Ritus in Poland und Russland seit Katharina II. bis auf unsere Tage. Mit einum Rückblick auf die Russische Kirche und ihrem Stellung zum heiligen Stuhle seit ihrem Entstehen bis auf Katharina II, wyd. A. Theiner, Augsburg 1841, s. 439 (I), 227-229 (II).

${ }_{2}^{2}$ J. Skarbek, Kościół katolicki w Rosji, [b.m.d.w.; mps], s. 11; S. Litak, Stosunki kościelne na ziemiach litewsko-ruskich w latach 1772-1815, w: Ziemie pótnocne Rzeczypospolitej polsko-litewskiej w dobie rozbiorowej 1772-1815. Materiały z konferencji międzynarodowej odbytej w dniach 11-14 maja 1995 r. w Toruniu, red. M. Biskup, Warszawa-Toruń 1996, s. 72-73.

3 W. Knapiński, Mohilewska archidiecezja i prowincja, w: Encyklopedia kościelna, t. 14, red. M. Nowodworski, Warszawa 1881, s. 532; J. Skarbek, Kościół rzymskokatolicki na Białorusi i Litwie w XIX i początkach XX stulecia, „Sympozjum” (1999), nr 3 (1), s. 13.

${ }^{4}$ Die neuesten Zustände der katholishen Kirche..., s. 533.

5 Relationes status dioecesium in Magno Ducatu Lituaniae, t. 2, red. P. Rabikauskas, Roma 19711978 (Fontes Historiae Lituaniae, t. 1-2), s. 378-381. 
W skład archidiecezji i metropolii mohylewskiej weszły także kościoły na terenach zabranych przez Rosję w II i III rozbiorze ${ }^{6}$. Znając przebieg granic poszczególnych zaborów oraz posługując się zestawieniami Stanisława Litaka, można stwierdzić, że w sumie na zajętych przez Rosję obszarach znajdowały się - przyjmując jako dane wyjściowe kościoły parafialne i filialne potwierdzone ok. 1772 r. - 693 kościoły parafialne i 587 kościołów filialnych. Jest to wielkość szacunkowa, jako że w ciągu dwóch dekad między I i III rozbiorem pojawiły się nowe świątynie, a inne uległy zniszczeniu lub likwidacji. Do państwa rosyjskiego trafiły cała diecezja inflancka, diecezja kijowska oraz smoleńska ${ }^{7}$. Inne diecezje zostały podzielone między Rosję i Prusy lub między Rosję i Austrię. W zaborze rosyjskim znalazły się:

- większa część diecezji kamienieckiej, poza świątyniami na prawym brzegu Zbrucza (części dekanatów: Jazłowiec i Czarnokozińce);

- większa część diecezji łuckiej, poza parafiami w dekanatach Krzemieniec i Zbaraż, które przypadły Austrii w I rozbiorze ${ }^{8}$, oraz poza parafiami

${ }^{6}$ Artykuł pomija analizę zmian w strukturach parafialnych i dekanalnych w trakcie czasowej reorganizacji biskupstw katolickich na ziemiach włączonych, dokonanej przez Katarzynę II w 1795 r. - likwidacja diecezji wileńskiej, inflanckiej, kijowskiej, kamienieckiej i łuckiej i powołanie diecezji inflanckiej, pińskiej i latyczowskiej. Na skutek braku zatwierdzenia papieskiego oraz przywrócenia dawnych biskupstw przez Pawła I w 1798 r., reorganizacja ta nie weszła w życie, B. Kumor, Granice metropolii i diecezji polskich 966-1939, Lublin 1972, s. 175-176; J. Skarbek, Kościół rzymskokatolicki na Białorusi..., s. 14.

7 Wszystkie wymienione diecezje ostatecznie zostały zniesione: smoleńska w momencie erygowania metropolii mohylewskiej w 1783 r., natomiast inflancka i kijowska w 1798 r., B. Kumor, Granice metropolii..., s. 49.

${ }^{8}$ Na skutek zmian terytorialnych wywołanych I rozbiorem diecezja łucka, która zasadniczo pozostała jeszcze w granicach państwa polskiego, utraciła 9 kościołów parafialnych: Szczurowice, Olesko, Brody, Załośce, Stanisławczyk, Podkamień (obsługiwany przez dominikanów), Opryłowce, Zbaraż, Ożochowce oraz 4 zakonne: Załośce (augustianie), Brody (dominikanie), Zbaraż (bernardyni), Olesko (kapucyni), ponadto dom szarytek przy parafii w Brodach, Relationes status dioecesium in Magno Ducatu Lituaniae..., t. 2, s. 206. W edycji znalazł się błąd redakcyjny: fragment „Eremitarum Sancti Augustini et Ordinis Praedicatorum in Brody” wskazuje na istnienie dwóch kościołów klasztornych w Brodach - augustianów i dominikanów; w źródłowym rękopisie brakuje wyrazu „et” („Eremitarum Sancti Augustini Ordinis Praedicatorum in Brody”), który został wstawiony prawdopodobnie w celu uczynienia tekstu poprawnym gramatycznie, Archivum Secretum Vaticanum (dalej: ASV), Congregatio Concilii, Relationes status: Luceoriensis 1788, k. 3; Relationes status dioecesium in Magno Ducatu Lituaniae..., t. 2, s. 235. Nie było kościoła klasztornego Augustianów w Brodach, zaś krytyka oryginalnego brzmienia zapisu wskazuje, że pisarz pominął najprawdopodobniej kościół klasztorny Augustianów w Załościach, w związku z czym tekst powinien brzmieć: „Eremitarum Sancti Augustini [in Załosce,] Ordinis Praedicatorum in Brody". Utrata kościoła parafialnego w Ożohowcach, który znalazł się w zaborze austriackim, nie oznaczała zaniku tej parafii w diecezji łuckiej, Źródła do dziejów rozgraniczenia diecezji łacińskich $w$ Cesarstwie Rosyjskim w połowie XIX wieku, t. 1, wyd. J. Skarbek, Lublin 2000; Relationes status dioecesium in Magno Ducatu Lituaniae..., t. 2, s. 235. Wykazy pomijają kościół w Leszniowie, który miał niejasny status w 1772 r., Słownik geograficzny Królestwa Polskiego i innych krajów słowiańskich (dalej: SGKP), t. 5, red. F. Sulimierski, B. Chlebowski, W. Walewski, Warszawa 1884, s. 176; J. Flaga, Zakony męskie w Polsce w 1772 roku, t. 2, cz. 1: Duszpasterstwo, 
położonymi po lewej stronie Bugu i w woj. podlaskim (całość lub części dekanatów: Janów Podlaski, Drohiczyn, Łosice, Węgrów, Brańsk, Bielsk Podlaski);

- większa część diecezji wileńskiej, poza parafiami po lewej stronie Niemna, w woj. trockim i podlaskim (całość lub części dekanatów: Augustów, Knyszyn, Grodno, Simno, Olwita, Kowno, Troki);

- większa część diecezji żmudzkiej, poza parafiami na południe od Niemna (część dekanatu Wielona);

- zabużańska część diecezji chełmskiej (dekanat Luboml z wyjątkiem parafii Dubienka).

Tabela 1. Liczba kościołów parafialnych i filialnych zajętych przez Rosję w latach 1772-17959

\begin{tabular}{|l|c|c|c|}
\hline \multirow{2}{*}{ Diecezja } & \multicolumn{2}{|c|}{ Liczba kościołów } & \multirow{2}{*}{ Suma } \\
\cline { 2 - 3 } & $\begin{array}{c}\text { parafialnych (w tym } \\
\text { parafii zakonnych) }\end{array}$ & $\begin{array}{c}\text { nieparafialnych } \\
\text { (filialnych i zakonnych) }\end{array}$ & \\
\hline Chełm & 8 & 3 & 11 \\
\hline Inflanty $^{10}$ & 33 & 50 & 83 \\
\hline Kamieniec Podolski & 47 & 20 & 67 \\
\hline Kijów & 31 & 11 & 42 \\
\hline Łuck $^{11}$ & 124 & 75 & 199 \\
\hline Smoleńsk & 2 & 4 & 661 \\
\hline Wilno & 352 & 309 & 211 \\
\hline Żmudź & 96 & 115 & 1280 \\
\hline Suma & 693 & 587 & \\
\hline
\end{tabular}

\section{Okres: 1795-1847}

\section{la. Okres: 1795-1807}

Jednymi z najważniejszych zagadnień o charakterze wstępnym, które należy podjąć przed analizą zmian w XIX w., są terminologia oraz określenie relacji między kościołami parafialnymi, pomocniczymi i kościołami zakonnymi. Różnice statystyczne zarówno w źródłach, jak i w literaturze przedmiotu wynikają często z niekonsekwentnego traktowania kategorii świątyń. Ma to znaczenie zwłaszcza

Lublin 1991 (Materiały do Atlasu Historycznego Chrześcijaństwa w Polsce, t. 8), s. 55-56; S. Litak, Atlas Kościoła łacińskiego w Rzeczypospolitej Obojga Narodów w XVIII wieku, Lublin 2006, s. 346; B. Kumor, Granice metropolii..., s. 187.

9 Obliczenie zostało wykonane na podstawie danych zawartych w atlasie Litaka oraz zasięgu zaboru rosyjskiego w 1795 r., S. Litak, Atlas Kościoła łacińskiego...

10 Statystyka uwzględnia kościół parafialny w Rydze jako należący już wcześniej do państwa rosyjskiego, a przynależący do diecezji inflanckiej, ibidem, s. 241.

11 Kościół we wsi Kołodno, należący przed rozbiorami do diecezji lwowskiej, został przyłączony do diecezji łuckiej po I rozbiorze na prośbę dziedzica wsi Leonarda Szwejkowskiego, Relationes status dioecesium in Magno Ducatu Lituaniae..., t. 2, s. 236. 
na terenach, gdzie istotną rolę, wobec braku w pełni rozwiniętych struktur parafialnych, odgrywało duszpasterstwo prowadzone przez zakony lub organizowane przy kościołach pomocniczych i prywatnych (filialnych, kaplicach czy oratoriach).

Wśród polskich prac poświęconych sytuacji Kościoła katolickiego w Rosji podstawowe znaczenie mają nadal dzieła ucznia Szymona Askenazego - Macieja Loreta ${ }^{12}$. Przytaczają one podstawowe statystyki dotyczące jego rozwoju administracyjnego w XIX w. Pewnym mankamentem tych opracowań, publikowanych na początku XX w., jest brak dokładnych wskazań źródłowych informacji. Porównanie statystyk podawanych przez Loreta $\mathrm{z}$ danymi zawartymi $\mathrm{w}$ sprawozdaniach legata Tomasza Arezza z 1804 r. dla diecezji metropolii mohylewskiej wskazuje, że było to podstawowe źródło danych statystycznych dla przełomu XVIII i XIX w., powielanych niezbyt dokładnie - w kolejnych opracowaniach. Za przykład niech posłuży fragment z dzieła Bolesława Kumora, dotyczący liczby parafii oraz duchowieństwa w archidiecezji mohylewskiej na przełomie XVIII i XIX w. „W r. 1798 archidiecezja liczyła 204 kościołów [sic!] pod zarządem księży diecezjalnych i 621 po zarządem zakonników, 186 kapłanów diecezjalnych i 78 zakonnych. W r. 1804 archidiecezja obejmowała 186 parafii, 74 klasztory męskie, 4 żeńskie, 204 kapłanów diecezjalnych, 621 zakonników, 44 zakonnice i 225.936 wiernych sposobnych do sakramentów św." ${ }^{13}$ Zastanawia pewna zbieżność liczby kościołów w 1798 r. z liczbą kapłanów diecezjalnych w 1804, liczby kościołów pod zarządem zakonników w 1798 r. z liczbą zakonników w 1804, liczby kapłanów diecezjalnych w 1798 r. z liczbą parafii w 1804 oraz liczby kapłanów zakonnych w 1798 r. z sumą liczby klasztorów męskich i żeńskich w 1804. Statystyka z 1798 r. została podana przez Kumora za artykułem Knapińskiego (nie K. Waberskiego), zawartym w Encyklopedii kościelnej w 1881 r. $^{14}$ Dane dla roku 1804 wskazał natomiast za, podstawowym dla badań dziejów Kościoła katolickiego w Rosji, wydawnictwem źródłowym Theinera z $1841 \mathrm{r}^{15}$, zauważając przy tym rozbieżność między nimi a informacjami podanymi w pracy Loreta ${ }^{16}$.

Wszyscy wymienieni autorzy (Knapiński, Loret, Kumor), a także kolejni badacze $^{17}$ korzystali najpewniej z dwóch sprawozdań posła Stolicy Apostolskiej Arezza

12 M. Loret, Kościół katolicki w początku panowania Aleksandra I (1801-1815), „Biblioteka Warszawska” 73 (1913), s. 493-520; idem, Kościót katolicki a Katarzyna II, 1772-1784, Kraków-Warszawa 1910 (Monografie w zakresie dziejów nowożytnych, t. 12). Cytowana równie często, np. przez B. Kumora, praca Stanisława Szantyra charakteryzuje w układzie chronologicznym zmiany w sytuacji Kościoła katolickiego w Rosji i nie przytacza istotnych statystyk czy wykazów świątyń, B. Kumor, Granice metropolii..., s. 173-198; S. Szantyr, Zbiór wiadomości o kościele i religii katolickiéj w Cesarstwie Rossyjskiem a szczególniéj w prowincyach od Polski przyłaczonych od czasu pierwszego rozbioru Polski aż do końca panowania cesarza Alexandra I. i początków panowania Mikołaja I, Poznań 1843.

13 B. Kumor, Granice metropolii..., s. 183.

${ }^{14}$ W. Knapiński, Mohilewska archidiecezja i prowincja..., s. 531-558.

${ }^{15}$ Die neuesten Zustände der katholishen Kirche..., s. 369.

${ }^{16}$ M. Loret, Kościót katolicki w początku panowania Aleksandra I..., s. 503.

17 L. Bieńkowski, Oświecenie i katastrofa rozbiorów (2. poł. XVIII w.), w: Chrześcijaństwo w Polsce. Zarys przemian 966-1979, red. J. Kłoczowski, Lublin 1992 (Biblioteka Historii Społeczno-Religijnej Instytutu Geografii Historycznej Kościoła w Polsce, t. 7), s. 352; Źródła do dziejów 


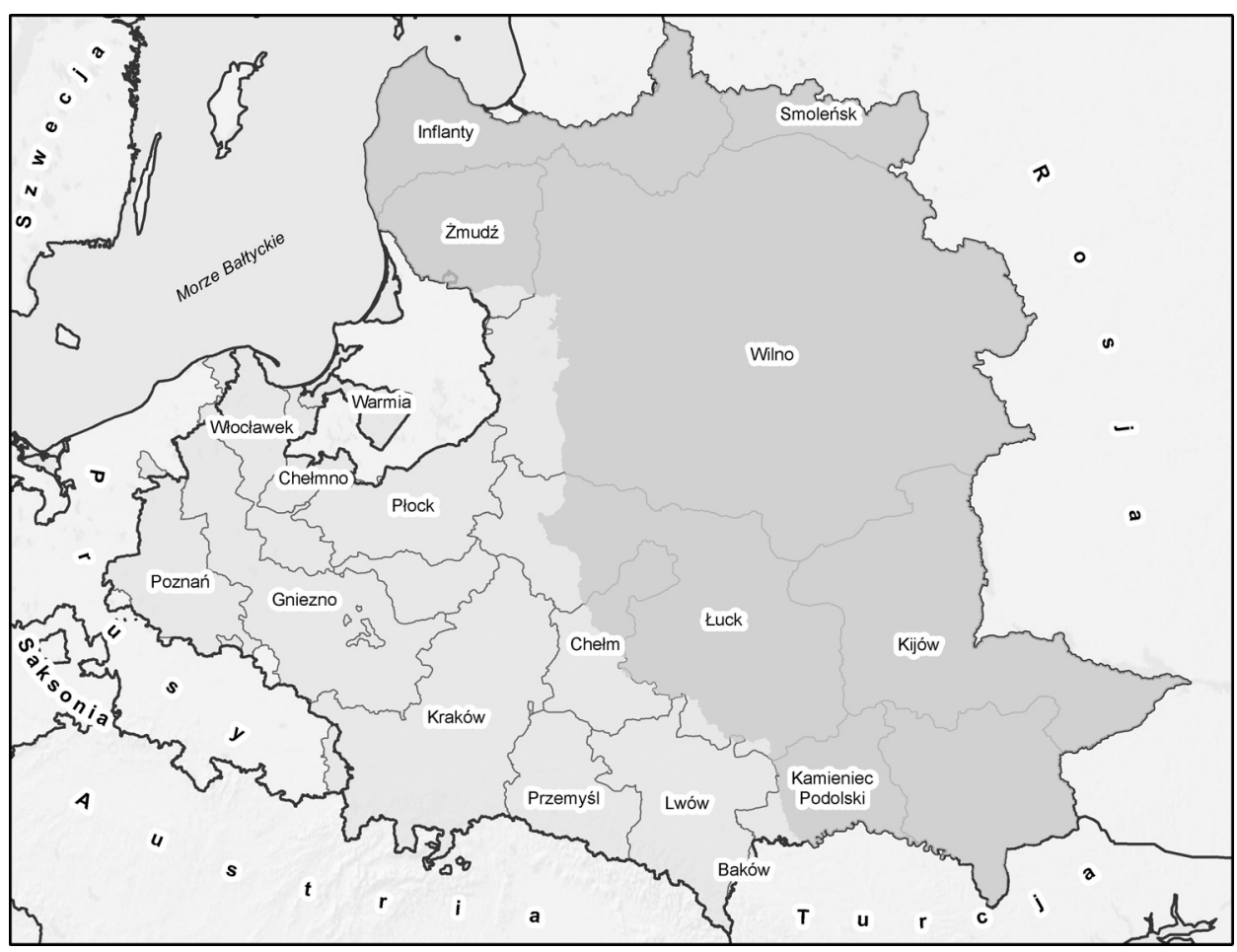

Rycina 1. Diecezje rzymskokatolickie włączone do zaboru rosyjskiego w latach 1772-1795 (ciemniejszy kolor). Mapa bazowa: ESRI World Shaded Relief, http://services.arcgisonline.com/ArcGIS/services.

z lat 1803 i 1804. Pierwsze zestawienie dołączone jest do relacji legata apostolskiego, przygotowanej tuż po opuszczeniu Petersburga w lipcu 1804 r. („Relazione dello stato attuale delle chiese cattoliche esistenti nell'impero Russo"), przedstawionej w Stolicy Apostolskiej w sierpniu 1807 r. Wcześniej, bo 28 sierpnia 1803 r. Arezzo wysłał list do Rzymu z podobną statystyką. Odrębnej analizy wymagałyby niewielkie różnice, jakie wystąpiły pomiędzy obu zestawieniami (tabela 2) obejmującymi diecezje metropolii mohylewskiej kilka lat po reorganizacji dokonanej przez Pawła I, następnie zatwierdzonej szeregiem dokumentów delegata apostolskiego Wawrzyńca Litty oraz papieża Piusa VI w $1798 \mathrm{r}^{18}$ Zasięg obszarów włączonych do Rosji w latach 1772-1795 na tle granic diecezji funkcjonujących w końcu istnienia Rzeczypospolitej Obojga Narodów przedstawia mapa 1.

rozgraniczenia diecezji..., s. XIII; J. Skarbek, Kościót katolicki w Rosji..., s. 75.

${ }^{18}$ Ludomir Bieńkowski w podsumowaniu o charakterze geograficzno-statystycznym podawał, że według stanu na ok. 1798 r. w metropolii mohylewskiej, która obejmowała 6 diecezji, znajdowało się 845, zaś podług innych danych 987 parafii rzymskokatolickich. Niestety w opracowaniu nie jest podane źródło tych statystyk, L. Bieńkowski, op. cit., s. 352. Można przypuszczać, że liczbę 845 parafii podał za opracowaniem Kumora, idem, Ustrój i organizacja Kościoła polskiego w okresie niewoli narodowej 1772-1918, Kraków 1980, s. 196. 
Prezentowane niżej zestawienie tabelaryczne (tabela 2), zawierające statystykę generalną dla poszczególnych diecezji wchodzących w skład metropolii mohylewskiej, może stanowić punkt wyjścia szczegółowych studiów nad biskupstwami. Przed ich rozpoczęciem należy podjąć wysiłek interpretacji zestawień sumarycznych, które występują w źródłach i opracowaniach dotyczących przełomu XVIII i XIX w. Niestety, nie można mieć wątpliwości, że podawanie liczby kościołów parafialnych w metropolii mohylewskiej za legatem Arezzem, a tak czyni większość opracowań, prowadzi do jej znacznego zaniżenia. Należy podkreślić, że zarówno informacje przekazane przez Arezzę z lat 1803-1804, jak też 30 lat późniejsze statystyki z 1834 r., opublikowane przez Theinera, dokonują wyraźnego podziału na kościoły i duchowieństwo świeckie oraz kościoły i duchowieństwo zakonne ${ }^{19}$. Określeniu "chiese parrocchiali” w listach legata z 1804 r. odpowiada rubryka „ecclesiae saeculares” w zestawieniach tabelarycznych dotyczących duchowieństwa świeckiego. Oznacza to, że liczby kościołów przekazane przez Arezza, zawarte pod określeniami „chiese parrocchiali” i „ecclesiae saeculares”, odnoszą się jedynie do kościołów parafialnych będących w zarządzie duchowieństwa świeckiego. Niestety zestawienia z lat 1803 i 1804 nie podają liczby kościołów parafialnych prowadzonych przez zakony, oddając jedynie ogólną liczbę kościołów zakonnych męskich i żeńskich (tabela 2). Nieco bardziej precyzyjne są statystyki dla 1834 r., gdyż w tabeli dotyczącej duchowieństwa zakonnego znajduje się informacja o 49 klasztorach męskich prowadzących parafie. Należy pamiętać, że liczba klasztorów prowadzących parafie przed kasatami w $1832 \mathrm{r}$. była kilkukrotnie wyższa. Z reguły w literaturze przedmiotu więcej uwagi poświęca się stratom w organizacji parafialnej, jakie przyniosły represje po powstaniu styczniowym, nie doceniając chyba, że w znacznym zakresie struktury parafialne w metropolii mohylewskiej ucierpiały na skutek kasat zakonnych (w tym zakonów prowadzących duszpasterstwo) po ukazie z $1832 \mathrm{r}$.

Kolejnym ważnym aspektem - poza różnym traktowaniem kościołów parafialnych świeckich i zakonnych - jest kwestia relacji między kościołami parafialnymi i filialnymi. To na pozór proste rozróżnienie stwarza bardzo wiele trudności przy analizie statystycznej opartej na schematyzmach. Na wstępnym etapie badań struktur terytorialnych metropolii mohylewskiej w XIX w. stanowią one podstawowe źródło historyczne. Niektóre ze schematyzmów zawierają podsumowania statystyczne, które klasyfikują zestawiane w nich świątynie. Bardzo ciekawe i wartościowe zestawienie, w kontekście kategoryzacji świątyń, znajduje się w schematyzmie diecezji wileńskiej z 1906 r. Zasługuje ono na przytoczenie w całości:

Ecclesiarum parochialium in gubernio Vilnensi ....................... 154

Ecclesiarum parochialium in gubernio Grodnensi $\ldots \ldots \ldots \ldots \ldots \ldots \ldots \ldots \ldots \ldots$

Ecclesiarum absque Parochia in gubernio Vilnensi $\ldots \ldots \ldots \ldots \ldots \ldots \ldots \ldots \ldots \ldots$

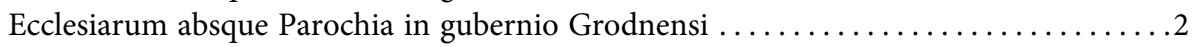

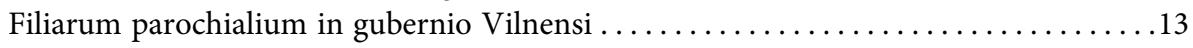

19 Die neuesten Zustände der katholishen Kirche..., s. 373. 


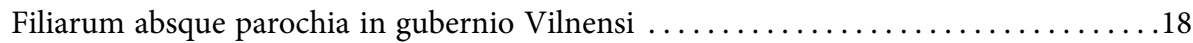

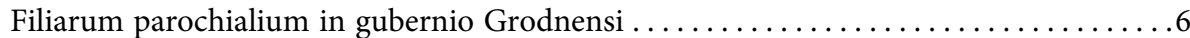

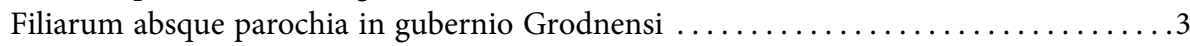

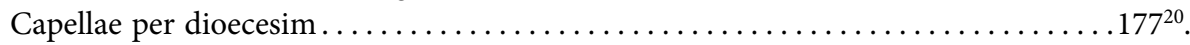

Jak widać z powyższej statystyki, już sam dychotomiczny podział kościołów na parafialne i filialne nie jest do końca poprawny, gdyż istniała grupa kościołów wyłączonych z tych kategorii. Bardziej dokładna analiza tego i innych schematyzmów wskazuje na dwa typy kościołów filialnych - część z nich posiadała okręgi parafialne (filie parafialne), a część nie. Ponieważ zagadnienie wymaga dodatkowych, szczegółowych badań, dla potrzeb dalszej prezentacji geograficznej i statystycznej będą brane pod uwagę tylko kościoły parafialne niefilialne, których status nie budził większych wątpliwości. Nie zostaną uwzględnione kościoły filialne, nawet jeżeli posiadały okręgi parafialne lub prowadzone było przy nich duszpasterstwo.

Wnioski dotyczące zaniżania $\mathrm{w}$ literaturze przedmiotu liczby parafii na początku XIX w. potwierdzają dane porównawcze pochodzące $\mathrm{z}$ innych źródeł rejestrujących sieć parafialną w tym okresie. Jako przykład może posłużyć rozbieżność między przedstawianym zestawieniem legata Arezza i relacją biskupa łucko-żytomierskiego Kacpra Kazimierza Cieciszowskiego z 1803 r. Relacja ta została wysłana 20 września 1803 r. przez Jana Kantego Podhorodeńskiego, wikariusza generalnego diecezji łuckiej, do legata Arezza. Można wnosić, że relacja bpa Cieciszowskiego ściśle wiąże się z przytoczonymi w tabeli sprawozdaniami legata. W relacji bpa Cieciszowskiego jest informacja, że diecezja dzieliła się na 12 dekanatów i składała się ze 117 parafii, 54 klasztorów („,52 conventi, 2 monasteri”), 278 księży diecezjalnych, 190 zakonników, 47 zakonnic ${ }^{21}$. We wszystkich kategoriach liczby te przewyższają dane przekazane przez legata Arezza do Stolicy Apostolskiej, szczególnie jeśli chodzi o liczbę parafii (o 34$)^{22}$. Z całą pewnością można stwierdzić, że liczba parafii podana przez bpa Cieciszowskiego uwzględnia zarówno parafie prowadzone przez duchowieństwo świeckie, jak i parafie zakonne. Wskazuje na to analiza schematyzmu z $1803 \mathrm{r}^{23}$

20 Directorium horarum canonicarum et missarum pro dioecesi Vilnensi in annum Domini communem 1906, Vilnae 1905, s. 202.

${ }^{21}$ Relationes status dioecesium in Magno Ducatu Lituaniae..., t. 2, s. 273-275.

${ }^{22}$ Jeszcze większe zamieszanie wprowadza literatura przedmiotu. „Po reorganizacji diecezji i połączeniu jej na równych prawach $\mathrm{z}$ diecezją żytomierską obydwa biskupstwa dzieliły się na 16 dekanatów, 146 parafii, a nadto liczyły 51 klasztorów męskich, 3 żeńskie, 214 kapłanów diecezjalnych, 502 zakonników, 51 zakonnic i 132800 wiernych”, B. Kumor, Granice metropolii..., s. 191. Żadne z podanych w przypisie opracowań nie zawiera takich danych. Autor oparł się prawdopodobnie na zestawieniu Arezza, przy czym pomylił niektóre kategorie.

${ }^{23}$ Podaje on dokładnie taką samą liczbę kościołów parafialnych, jak relacja bpa Cieciszowskiego 117. Wątpliwości może budzić potraktowanie jako kościołów parafialnych 3 kościołów zakonnych: Radziechów (augustianie), Janów oraz Kustyń (bernardyni) oraz kaplicy publicznej w Andruszówce. Directorium officii divini ac missarum ad usum dioecesis Luceoriensis pro anno Domini 1803, Luceoriae [b.d.w.]. 
Rozbieżności dotyczące stanu organizacyjnego występują także między relacją „ad limina” biskupa mińskiego Jakuba Ignacego Dederki a zestawieniem przekazanym w korespondencji legata Arezza. Relacja biskupa dzieli diecezję mińską na 12 dekanatów, z 74 kościołami parafialnymi i 13 filialnymi, 77 kościołami zakonnymi oraz 20 oratoriami. Liczba duchowieństwa świeckiego miała wynosić 88 , zakonników - 383 i zakonnic - $108^{24}$. Istotne uzupełnienie tej statystyki przynosi bardziej szczegółowy, opublikowany przez Mariana Radwana, raport tego samego biskupa z 1802 r. Wynika z niego jasno, że liczba 74 kościołów parafialnych dotyczy tylko „świeckich” i należy ją poszerzyć o 26 kościołów parafialnych zakonnych. W tym wypadku porównanie i krytyka informacji źródłowych wskazują na dość znaczne niedoszacowanie liczby parafii $\mathrm{w}$ relacji biskupa.

Dla pozostałych diecezji metropolii mohylewskiej, powołanych w $1798 \mathrm{r}$., nie są znane relacje biskupów, które można zestawić ze sprawozdaniami legata Arezza. Materiał porównawczy do statystyk legata Arezza dla archidiecezji mohylewskiej przynoszą schematyzmy z początku XIX w. (1803, 1808, 1820). Przy ich analizie należy brać pod uwagę zmianę terytorium archidiecezji, wywołaną wojnami napoleońskimi (pokój w Tylży w 1807 r.), które spowodowały powiększenie terytorium archidiecezji o okręg białostocki. Nie można wykluczyć, że uwzględnienie lub pominięcie kościołów okręgu białostockiego było powodem dużej różnicy w liczbie świątyń archidiecezji mohylewskiej podanej w sprawozdaniach legata Arezza (tabela 2). Ze względu na cel porównawczy dokonywanych obliczeń należy brać pod uwagę także kościoły parafialne położone na tym terenie, który pozostał $\mathrm{w}$ granicach archidiecezji do połowy XIX w. W świetle schematyzmu z 1803 r., który nie uwzględnia okręgu białostockiego, do archidiecezji mohylewskiej należało 219 kościołów parafialnych ${ }^{25}$. Do tej liczby trzeba doliczyć kościoły okręgu białostockiego, które weszły w skład archidiakonatu białostockiego $^{26}$. Zgodnie $\mathrm{z}$ relacją biskupa wigierskiego Jana Klemensa Gołaszewskiego z 1812 r. miało to być 55 kościołów parafialnych ${ }^{27}$. W sumie więc były w archidiecezji mohylewskiej na początku XIX w., po włączeniu do niej okręgu białostockiego, 274 kościoły parafialne. Bardzo zbliżoną liczbę - 273 - podaje schematyzm archidiecezji z $1820 \mathrm{r}^{28}$

${ }^{24}$ Relationes status dioecesium in Magno Ducatu Lituaniae..., t. 2, s. 447.

${ }^{25} \mathrm{~W}$ trzech sytuacjach parafialny charakter świątyń budzi wątpliwości: po dwie parafie wymienione są w Tołoczynie, Oświeju i Rosicy. Directorium officii divini et missarum generale pro utroque clero archidioecesis Mohyloviensis in annum Domini 1803, Polociae [b.d.w.].

26 A. Szot, Dekanat białostocki w 1849 r., „Studia Teologiczne. Białystok, Drohiczyn, Łomża” 26 (2008), s. 489.

27 Relationes status dioecesium in Magno Ducatu Lituaniae..., t. 2, s. 456. Nieco odmienne statystyki podaje Kumor - 53 parafie i 6 filii, B. Kumor, Granice metropolii..., s. 234.

${ }^{28}$ Niższą liczbę (229) podaje schematyzm z 1808 r., jednak należy wziąć pod uwagę, że uwzględnił on tylko część okręgu białostockiego. Spisek łacińskiego duchowieństwa mohilewskiey archi-dyecezyi roku 1808, [b.m.d.w.], s. 9-21; Directorium officii divini et missarum generale pro utroque clero archidioecesis Mohiloviensis, Mohileviae 1820. 
$\mathrm{Na}$ trudności $\mathrm{w}$ ustaleniu liczby parafii diecezji wileńskiej na przełomie XVIII i XIX w. zwracał uwagę Jan Skarbek, przyjmując jako najprawdopodobniejszą liczbę 400 kościołów parafialnych i filialnych ${ }^{29}$. Należy podkreślić, że dopiero od $1851 \mathrm{r}$. pojawiały się pierwsze wykazy kościołów w schematyzmach wileńskich ${ }^{30}$. Pewne rozwiązanie przynosi tutaj zestawienie mapy diecezji wileńskiej, opracowanej przez Skarbka dla $1825 \mathrm{r}^{31}, \mathrm{z}$ bardziej szczegółowymi informacjami dotyczącymi daty erygowania kościołów parafialnych. Analiza taka pozwala oszacować liczbę kościołów parafialnych diecezji wileńskiej w początku XIX w. (ok. 1803 r.) na $317^{32}$. Z niewiadomych przyczyn zestawienie świątyń z $1825 \mathrm{r}$. pominęło parafie w miejscowościach Sehmen (Sēme) - Lievenhof (Lamini), w dekanacie kurlandzkim ${ }^{33}$, Stare Troki ${ }^{34}$, Trokiele ${ }^{35}$, Lipniszki ${ }^{36}$, Koleśniki ${ }^{37}$, Porozów ${ }^{38}$, Łysków ${ }^{39}$,

29 J. Skarbek, Organizacja parafialna $w$ diecezji wileńskiej w latach 1772/3-1914, „Studia Teologiczne. Białystok, Drohiczyn, Łomża” 5-6 (1987-1988), s. 120.

30 T. Krahel, Schematyzmy diecezji wileńskiej jako źródło historyczne, Lublin 1979, s. 31.

31 J. Skarbek, Organizacja parafialna $w$ diecezji wileńskiej..., mapa: Diecezja wileńska 1825.

${ }^{32}$ Ustalenie jest zbieżne z informacją, że w $1840 \mathrm{r}$. w diecezji wileńskiej znajdowały się 323 parafie. Przyrost liczby parafii w diecezji wileńskiej w latach $1806-1840$ był znikomy (5 parafii), ibidem, s. 121.

${ }^{33}$ Parafię w Sehmen (Sēme) - Lievenhof (Lamini) pomijają zarówno zestawienia Litaka (1772 r.), jak i mapa Skarbka (1825 r.). Słownik geograficzny Królestwa Polskiego i innych krajów słowiańskich wspomina o parafialnym kościele św. Jerzego we wsi Liwenhof (Lievenhof) z 1748 r. Nie może być to informacja wiarygodna, gdyż wizytacja diecezji inflanckiej z $1761 \mathrm{r}$. nie wymienia tej świątyni $\mathrm{w}$ swoim zestawieniu. Pojawia się ona w pracy C.L. Tetscha z 1767 r. oraz w latach następnych. Rodzina von Lieven ufundowała najpierw kościół w swoich dobrach Sehmen, a następnie w pobliskim Lievenhof (w 1792 r.), przy czym była to jedna parafia (w latach 1813 i 1821 jako jej pleban wymieniany jest Michał Trajanowski). S. Litak, Atlas Kościoła łacińskiego..., s. 240-241; J. Skarbek, Organizacja parafialna $w$ diecezji wileńskiej..., mapa: Diecezja wileńska 1825; SGKP, t. 5, Warszawa 1884, s. 356; Akta wizytacji generalnej diecezji inflanckiej i kurlandzkiej czyli piltyńskiej z 1761 roku, wyd. S. Litak, Toruń 1998, s. 298-300; C.L. Tetsch, Curländischer- Kirchengeschichte, von dem Zustande dieser Provincial-Kirche, bis zum Ableben Gotthards ersten Herzogs $z u$ Curland, nebst der gegenwärtigen äusserlichen kirchlichen Verfassung dieses Herzogthums, t. 1, Riga-Leipzig 1767, s. 281 (dalej: Curländische Kirchengeschichte); E. v. Fircks, Neue Kurländische Güter-Chroniken, Mitau 1900, s. 38-39; Directorium horarum canonicarum et missarum pro dioecesi Vilnensi in annum Domini 1821, Vilnae [b.d.w.].

${ }^{34}$ K. Misius, R. Šinkūnas, Lietuvos katalikų bažnyčios. Žinynas, Vilnius 1993, s. 568-569.

35 Józef Sągayło, „administrator” w Trokielach w 1821 r. Directorium... Vilnensi... 1821...; Cnucok римско-католических духовных лии н учреждении, Санкт-Петербург 1853, s. 69; Directorium horarum canonicarum et missarum pro dioecesi Vilnensi in annum Domini 1857, Vilnae 1856, s. 88; S. Litak, Atlas Kościoła łacińskiego..., s. 306.

36 Jakub Michałowski, „curatus” w Lipsznikach w 1821 r. Directorium... Vilnensi... 1821...; Cnucoк римско-католических духовных тии..., s. 60; Directorium... Vilnensi... 1857..., s. 84; S. Litak, Atlas Kościoła łacińskiego..., s. 306.

37 K. Misius, R. Šinkūnas, op. cit., s. 581.

38 Powodem pominięcia Porozowa mógł być brak kościoła parafialnego po pożarze 1797 r. Przez 20 lat, do czasu wybudowania nowego kościoła (1825 lub 1828 r.), nabożeństwa odprawiano w szopie, J. Kurczewski, Biskupstwo wileńskie, Wilno 1912, s. 228; SGKP, t. 8, Warszawa 1887, s. 826.

39 Directorium... Vilnensi... 1857..., s. 95; Список римско-католических духовных лии..., s. 83; J. Kurczewski, op. cit., s. 230; S. Litak, Atlas Kościoła łacińskiego..., s. 306. 
Dereczyn $^{40}$. Poważne wątpliwości budzi przypisanie przez Skarbka niektórym kościołom i kaplicom praw parafialnych: Plusy ${ }^{41}$, Kaczergiszki ${ }^{42}$, Widziszki ${ }^{43}$, Dudy $^{44}$, Dubicze ${ }^{45}$, Narewka ${ }^{46}$, Skrundzie ${ }^{47}$, Walówka ${ }^{48}$. Z kolei kościołowi parafialnemu w Widziniszkach nadano status kościoła filialnego ${ }^{49}$. Nie udało się także jednoznacznie potwierdzić funkcjonowania przed 1804 r. następujących parafii ujętych na mapie diecezji wileńskiej w 1825 r.: Liewenbersen ${ }^{50}$, Upita ${ }^{51}$, Subocz Stary ${ }^{52}$, Smelin $^{53}$, Murowana Oszmianka ${ }^{54}$, Krzywsk $^{55}$.

40 Список римско-католических духовных лиц..., s. 85; Directorium... Vilnensi... 1857..., s. 96; J. Kurczewski, op. cit., s. 232-233; S. Litak, Atlas Kościoła łacińskiego..., s. 306.

${ }^{41}$ Список римско-католических духовных лии..., s. 136; Directorium horarum canonicarum et missarum pro dioecesi Telsensi seu Samogitiensi in annum Domini 1859, Vilnae 1858, s. 96.

42 Список римско-католических духовных лиц..., s. 64; Directorium... Vilnensi... 1857..., s. 85.

${ }^{43}$ Directorium... Vilnensi... 1821... (Adam Elbowicz, filialis Widziscensis); Список римско-католических духовных лии..., s. 109; Directorium... Telsensi... 1859..., s. 112.

${ }^{44}$ Список римско-католических духовных лиц..., s. 62; Directorium... Vilnensi... 1857..., s. 85; S. Litak, Atlas Kościoła łacińskiego..., s. 306; J. Kurczewski, op. cit., s. 199.

45 Słownik geograficzny Królestwa Polskiego i innych krajów słowiańskich wspomina co prawda, że przed „10 laty stał tu kościół niegdyś parafialny, potem filia kościoła w Naczy”, ale nie znajduje to potwierdzenia w innych źródłach i opracowaniach, Список римско-католических духовных лии..., s. 68; Directorium... Vilnensi... 1857..., s. 88; J. Kurczewski, op. cit., s. 213; W.A. Sułkowski, Kartka z dziejów kościoła katolickiego w Polsce rosyjskiej. Biskupstwo wileńskie, Kraków 1889, s. 263; K. Misius, R. Šinkūnas, op. cit., s. 580; S. Litak, Atlas Kościoła łacińskiego..., s. 306.

${ }^{46}$ Nie ma jednoznacznych przesłanek do twierdzenia, że w Narewce w XIX w. funkcjonowała samodzielna parafia. Na podstawie opracowania Tadeusza Kalińskiego można wnosić, że była to filia parafialna. Directorium... Vilnensi... 1857..., s. 94; W.A. Sułkowski, Kartka $z$ dziejów Kościoła katolickiego w Polsce rosyjskiej..., s. 308; T. Kaliński, Monografia parafii Narewka, [b.d.m.w.], s. 14, http://www.narewka.archibial.pl/files/Historia_parafii_Narewka.pdf (dostęp: 30.03.2016).

47 Список римско-католических духовных лиц..., s. 84; Directorium... Vilnensi... 1857..., s. 95; W.A. Sułkowski, Kartka z dziejów Kościoła katolickiego w Polsce rosyjskiej..., s. 320; J. Kurczewski, op. cit., s. 234.

${ }^{48}$ Nie udało się ustalić podstawy źródłowej nadania kościołowi w Walówce statusu świątyni parafialnej. Znajdowały się w tej miejscowości kościół i klasztor Dominikanów, który został zamknięty w 1832 r., SGKP, t. 12, Warszawa 1892, s. 916-917; P.P. Gach, Kasaty zakonów na ziemiach dawnej Rzeczypospolitej i Śląska 1773-1914, Lublin 1984, s. 250.

49 S. Litak, Atlas Kościoła łacińskiego..., s. 311; Список римско-католических духовных лиц..., s. 45; Directorium... Vilnensi... 1857..., s. 80. O funkcjonowaniu parafii w Widziniszkach mogą świadczyć akta metrykalne z lat 1802-1818. Należała wówczas do dekanatu Pobojsk, Lietuvos Valstybės Istorijos Archyve (dalej: LVIA), f. 604, ap. 10, b. 35, Videniškių Romos katalikų parapijinès bažnyčios 1802-1818 m. gimimo, santuokos ir mirties metrikų; 1802-1818 m. Želvos filijinès bažnyčios gimimo ir mirties metrikų; $1813 \mathrm{~m}$. Lelikonių filijinès bažnyčios gimimo ir mirties metrikų nuorašų knyga. 1802-1818 m., http://www.epaveldas.lt/object/recordDescription/ ARCH/604/10/35 (dostęp: 29.03.2016).

${ }^{50}$ Wiadomo, że kościół został przekształcony na katolicki w 1729 r. Od połowy XVIII w. funkcjonowała przy nim misja jezuicka. E. v. Fircks, op. cit., s. 38; Encyklopedia wiedzy o jezuitach na ziemiach Polski i Litwy, 1564-1995, red. L. Grzebień, Kraków 1996.

${ }^{51}$ Wizytacja parafii Nowe Miasto z $1784 \mathrm{r}$. mówi o kościele filialnym w Upicie, Ukmergés dekanato vizitacija 1784 m., atlikta Vilniaus vyskupo Ignoto Jokūbo Masalskio parèdymu, wyd. S. Jegelevičius, Vilnius 2009 (Fontes historiae Lituaniae, t. 8), s. 180. 
Równie trudne, jak w przypadku diecezji wileńskiej, jest ustalenie dokładnej liczby kościołów parafialnych na początku XIX w. w diecezji kamienieckiej ${ }^{56}$. Pełną ich listę podaje schematyzm diecezji z $1817 \mathrm{r}$. Wykaz ten ujmuje także kościoły, które powstały na początku XIX w., np. Krzywe Jezioro (eryg. 1807 r.), Dzygówka (eryg. 1805 r.), Supruńkowce (eryg. 1809 r.), Zamiechów (eryg. 1808 r.), Ładyżyn (eryg. 1823), Obodówka (eryg. 1822). Wykaz omyłkowo powtórzył dwa razy miasteczko Zińkowce, zaś pominął Żwaniec ${ }^{57}$. Po odliczeniu parafii erygowanych po $1803 \mathrm{r}$. oraz tych, gdzie prawa parafialne na początku XIX w. budzą wątpliwości ${ }^{58}$, okazało się, że ich liczba ok. 1804 r. wynosiła 81 i także przewyższała podaną w relacjach przez legata Arezza.

Bardzo wątpliwą liczbę parafii (171) zestawienie legata Arezza przynosi w stosunku do diecezji żmudzkiej. Dotyczy to zarówno rubryki w tabeli zbiorczej z sierpnia 1803 r. ${ }^{59}$, jak i relacji o stanie diecezji żmudzkiej z lipca

52 Można przypuszczać, że podobnie jak inne misje pojezuickie w okolicach Iłłukszty (Bebra, Dweta), parafia w Suboczu Starym uzyskała samodzielność w 1783 r., jednak nie ma bezpośredniej przesłanki źródłowej, Encyklopedia wiedzy o jezuitach..., s. 651.

${ }^{53}$ S. Litak, Atlas Kościoła łacińskiego..., s. 241; J. Skarbek, Organizacja parafialna $w$ diecezji wileńskiej..., mapa: Diecezja wileńska 1825.

${ }^{54}$ W.A. Sułkowski, Kartka z dziejów Kościoła katolickiego w Polsce rosyjskiej..., s. 229; J. Kurczewski, op. cit., s. 196; S. Litak, Atlas Kościoła łacińskiego..., s. 304.

55 Źródła informują o kaplicy parafii Krewo. Directorium... Vilnensi... 1857..., s. 83; Список римскокатолических духовных лии..., s. 59; J. Kurczewski, op. cit., s. 197; W.A. Sułkowski, Kartka $z$ dziejów Kościoła katolickiego w Polsce rosyjskiej..., s. 231.

56 Trudno określić, na jakiej podstawie Kumor podał liczbę 102 parafii w diecezji kamienieckiej w 1804 r. Prawdopodobnie zsumował liczby wszystkich kościołów, zarówno diecezjalne (świeckie), jak i zakonne - męskie i żeńskie, w tej diecezji podane przez legata Arezza, B. Kumor, Granice metropolii..., s. 186.

57 Pojawienie się w wykazie z 1817 r. kościoła w Ładyżynie kłóci się z informacją o budowie kościoła w 1823 r. Schematyzm odnosi się prawdopodobnie do drewnianej kaplicy istniejącej wcześniej, a wybudowanej w 1797 r. Podobna sytuacja jest z kościołem w Obodówce (budowa kościoła 1807 lub 1808 r., erygowanie parafii prawdopodobnie w 1822 r.), Directorium officii divini ac missarum dioecesis Camenecensis Podoliae in annum Christi 1817, Berdiczoviae [b.d.w.]; Źródła do dziejów rozgraniczenia diecezji..., s. 26, 29, 31-32, 35, 43, 46-47.

58 Pogłębionej analizy na podstawie szerszej podstawy źródłowej wymaga sytuacja parafii w Mińkowcach. Według Skarbka miała być ona erygowana już w 1797 r., jednak podstawa źródłowa tego wniosku jest dość wątła. W schematyzmie z 1817 r. pojawia się sformułowanie „Minkowce Capel.”, co wskazuje raczej na kaplicę lub obsługę przez kapelana. Rozbieżne informacje są podawane także odnośnie do daty powołania parafii franciszkanów konwentualnych w Komargrodzie. Według Litaka i Ludwika Królika w okresie staropolskim nie było parafii przy tym klasztorze. Z kolei Jan Marek Giżycki uważa, że był to kościół parafialny od samego początku, Directorium... Camenecensis... 1817...; Źródła do dziejów rozgraniczenia diecezji..., s. 36; Wołyniak [J.M. Giżycki], Zniesione kościoły i klasztory rzymsko-katolickie przez rząd rosyjski w wieku XIX-tym w diecezji łuckiej, żytomierskiej i kamienieckiej (gub. wołyńskiej, kijowskiej i podolskiej), „Nova Polonia Sacra” 1 (1928), s. 267; S. Litak, Atlas Kościoła łacińskiego..., s. 345; L. Królik, Organizacja diecezji łuckiej i brzeskiej od XVI do XVIII wieku, Lublin 1983, s. 368.

59 Die neuesten Zustände der katholishen Kirche..., s. 369; Nonciature d'Arezzo 1802-1806, t. 1: 1802-1804, wyd. M.J. de Journel, Città del Vaticano 1922 (Studi e testi, t. 168-169), s. 248 (dalej: Nonciature d'Arezzo 1802-1806). 
$1804 \mathrm{r}^{60} \mathrm{~W}$ świetle innych źródeł informację tę należy uznać za pomyłkę (być może legat podał sumarycznie liczbę kościołów parafialnych i pomocniczych). Wcześniejsze sprawozdania bpa Jana Stefana Giedroycia podają liczby zdecydowanie niższe: w 1788 r. - 97 kościołów parafialnych, w 1793 r. - 91 ${ }^{61}$. Wiarygodne zestawienie parafii na podstawie wizytacji diecezji żmudzkiej z lat 1820-1821 zostało wykonane przez Aldonę Prašmantaite - w 11 dekanatach znajdowało się 110 parafii $^{62}$. Najbardziej prawdopodobna szacunkowa liczba kościołów parafialnych w diecezji żmudzkiej w momencie przygotowywania relacji przez nuncjusza Arezza wynosiła $105^{63}$.

Podsumowując te krótkie rozważania dotyczące organizacji parafialnej na terenie metropolii mohylewskiej w początkach jej istnienia, należy odrzucić zestawienia sumaryczne $\mathrm{z}$ raportów legata Arezza z lat 1803-1804, które zaniżyły liczbę kościołów parafialnych przez nieuwzględnienie kościołów zakonnych. Tym bardziej ostrożnie, co zostało wykazane wyżej, należy podchodzić do statystyk prezentowanych w literaturze przedmiotu, które zazwyczaj opierały się na wspomnianych raportach. Chyba najbardziej rażące błędy zostały zawarte w tabeli podsumowującej liczbę parafii oraz duchowieństwa rzymskokatolickiego na ziemiach zabranych w 1804 r., znajdującej się w pracy Kumora, pt. Ustrój i organizacja Kościoła polskiego w okresie niewoli narodowej 1772-1918 (s. 196). Liczbę kapłanów diecezjalnych zaniżono tam niemal trzykrotnie (642 zamiast ok. 1700), natomiast liczbę kościołów zakonnych zawyżono prawie pięciokrotnie (1710 zamiast ok. 350). O wiele bardziej precyzyjne, i zbliżone do podanych $w$ tabeli 2 , są dane przytoczone przez Ludomira Bieńkowskiego w podsumowaniu geograficzno-statystycznym dla Kościoła katolickiego na ziemiach zabranych ok. 1798 r. Podawał on, że według stanu na ok. 1798 r. w metropolii mohylewskiej, która obejmowała 6 diecezji, znajdowało się 845, zaś według innych danych - 987 parafii rzymskokatolickich. Można przypuszczać, że liczbę 845 parafii wskazał za opracowaniem Kumora lub raportami legata Arezza. Drugi z szacunków Bieńkowskiego (niestety bez podstawy źródłowej) jest bardzo zbliżony do statystyki podanej niżej (994 parafie) $)^{64}$.

${ }^{60}$ Relationes status dioecesium in Magno Ducatu Lituaniae..., t. 1, s. 464. Dość bezkrytycznie dane te powtórzył Kumor, dokonując jeszcze dodatkowych uproszczeń - podał on liczbę 171 parafii dla $1804 \mathrm{r}$. oraz 164 parafii dla $1834 \mathrm{r}$. za wydawnictwem Theinera. W zestawieniu z $1834 \mathrm{r}$. Theiner podaje, że w diecezji żmudzkiej znajdowało się 105 kościołów parafialnych, 59 pomocniczych oraz 92 kaplice. B. Kumor, Ustrój i organizacja..., s. 674; Die neuesten Zustände der katholishen Kirche..., s. 373.

${ }^{61}$ Relationes status dioecesium in Magno Ducatu Lituaniae..., t. 1, s. 441.

62 A. Prašmantaitė, Žemaičiu vyskupas Juozapas Arnulfas Giedraitis, Vilnius 2000, s. 123.

${ }^{63}$ Od liczby parafii podanej w wizytacji z lat 1820-1821 należy odjąć parafie powołane do istnienia w latach 1803-1804 (Odachów, Girdyszki, Skaudwile, Krupie i Łaukożemy), ibidem, s. 105-106; M. Wołonczewski, Biskupstwo żmujdzkie, Kraków 1898, s. 118-119.

${ }^{64}$ L. Bieńkowski, op. cit., s. 352. 
Tabela 2. Liczba kościołów oraz duchowieństwa w metropolii mohylewskiej w latach 1803-1804

\begin{tabular}{|c|c|c|c|c|c|c|c|c|c|}
\hline \multirow{4}{*}{ Diecezja } & \multirow{4}{*}{$\begin{array}{c}\text { Liczba } \\
\text { kościołów } \\
\text { parafialnych }^{65}\end{array}$} & \multicolumn{8}{|c|}{ Relacje i zestawienia legata T. Arezza } \\
\hline & & & \multicolumn{3}{|c|}{ Kościoły } & \multicolumn{3}{|c|}{ Duchowieństwo } & \multirow{3}{*}{ Parafianie } \\
\hline & & & \multirow{2}{*}{$\begin{array}{c}\text { A. } \\
\text { diecezjalne } \\
\text { B. parafialne }\end{array}$} & \multicolumn{2}{|c|}{ zakonne } & \multirow{2}{*}{ diecezjalne } & \multicolumn{2}{|c|}{ zakonne } & \\
\hline & & & & męskie & żeńskie & & męskie & żeńskie & \\
\hline \multirow{2}{*}{ mohylewska } & \multirow{2}{*}{274} & A & 186 & 70 & 8 & 204 & 621 & 44 & 225936 \\
\hline & & $\mathrm{B}$ & 159 & 66 & 8 & 204 & $534^{66}$ & 44 & 225936 \\
\hline \multirow{2}{*}{ wileńska } & \multirow{2}{*}{317} & A & 269 & 101 & 18 & 626 & 1229 & 364 & 736027 \\
\hline & & $\mathrm{B}$ & 272 & 106 & $19^{67}$ & 626 & 1229 & $343^{68}$ & 736027 \\
\hline \multirow{2}{*}{ żmudzka } & \multirow{2}{*}{105} & A & 171 & 17 & 2 & 388 & 198 & 36 & 275348 \\
\hline & & B & 171 & 14 & 3 & 338 & 186 & 40 & 279632 \\
\hline \multirow{2}{*}{ łucko-żytomierska } & \multirow{2}{*}{117} & A & 83 & 60 & 3 & $214^{69}$ & 550 & 51 & 132800 \\
\hline & & B & 83 & 57 & $3^{70}$ & 214 & $499^{71}$ & 51 & 132800 \\
\hline \multirow{2}{*}{ kamieniecka } & \multirow{2}{*}{81} & A & 74 & 27 & 1 & 142 & 195 & 16 & 153105 \\
\hline & & B & 74 & 25 & 1 & 122 & 197 & 6 & 153185 \\
\hline
\end{tabular}

65 Zob. s. $13-18$.

66524 (z podsumowania wynika 534), Nonciature d'Arezzo 1802-1806, t. 2, s. 436; Relationes status dioecesium in Magno Ducatu Lituaniae..., t. 2, s. 419.

${ }^{67} 18$ (z podsumowania wynika 19), Nonciature d'Arezzo 1802-1806, t. 2, s. 439.

68323 (z podsumowania wynika 343), ibidem, s. 439.

69244 (błędnie), ibidem, t. 1, s. 248.

702 (z podsumowania wynika 3), Relationes status dioecesium in Magno Ducatu Lituaniae..., t. 2, s. 283.

71498 (z podsumowania wynika 499), Nonciature d'Arezzo 1802-1806, t. 2, s. 444; Relationes status dioecesium in Magno Ducatu Lituaniae..., t. 2, s. 283. 
Tabela 2. cd.

\begin{tabular}{|c|c|c|c|c|c|c|c|c|c|}
\hline \multirow{4}{*}{ Diecezja } & \multirow{4}{*}{$\begin{array}{c}\text { Liczba } \\
\text { kościołów } \\
\text { parafialnych }\end{array}$} & \multicolumn{8}{|c|}{ Relacje i zestawienia legata T. Arezza } \\
\hline & & & \multicolumn{3}{|c|}{ Kościoły } & \multicolumn{3}{|c|}{ Duchowieństwo } & \multirow{3}{*}{ Parafianie } \\
\hline & & & \multirow{2}{*}{$\begin{array}{c}\text { A. } \\
\text { diecezjalne } \\
\text { B. parafialne }\end{array}$} & \multicolumn{2}{|c|}{ zakonne } & \multirow{2}{*}{ diecezjalne } & \multicolumn{2}{|c|}{ zakonne } & \\
\hline & & & & męskie & żeńskie & & męskie & żeńskie & \\
\hline \multirow{2}{*}{ mińska } & \multirow{2}{*}{100} & A & 94 & 44 & 5 & 143 & 353 & 108 & 112274 \\
\hline & & B & 86 & 50 & 8 & 156 & $435^{72}$ & 77 & 112214 \\
\hline \multirow{2}{*}{ RAZEM } & \multirow{2}{*}{994} & A & 877 & 319 & 37 & $1717^{73}$ & 3146 & 619 & 1635490 \\
\hline & & B & 845 & 318 & 42 & 1660 & 3080 & 561 & 1639794 \\
\hline
\end{tabular}

A. (28 sierpnia 1803 r.) Die neuesten Zustände der katholishen Kirche beider Ritus in Poland und Russland seit Katharina II. bis auf unsere Tage. Mit einum Rückblick auf die Russische Kirche und ihrem Stellung zum heiligen Stuhle seit ihrem Entstehen bis auf Katharina II, wyd. A. Theiner, Augsburg 1841, s. 369; Nonciature d'Arezzo 1802-1806, t. 1: 1802-1804, wyd. M.J. de Journel, Città del Vaticano 1922 (Studi e testi, t. 168-169), s. 248.

B. (lipiec 1804 r.) Nonciature d'Arezzo 1802-1806, t. 2: 1804-1806, wyd. M.J. de Journel, Città del Vaticano 1922 (Studi e testi, t. 168-169), s. 446 (dalej: Nonciature d'Arezzo 1802-1806); Relationes status dioecesium in Magno Ducatu Lituaniae, red. P. Rabikauskas, t. 1, Roma 1971-1978 (Fontes historiae Lituaniae, t. 1-2), s. 218-219 (diec. wileńska), 464-465 (diec. żmudzka); t. 2, s. 282-283 (diec. łucka), 418-419 (diec. mohylewska), 450-451 (diec. mińska).

72425 (z podsumowania wynika 435), Nonciature d'Arezzo 1802-1806, t. 2, s. 447; Relationes status dioecesium in Magno Ducatu Lituaniae..., t. 2, s. 450.

73 1718, Nonciature d'Arezzo 1802-1806, t. 1, s. 248. 


\section{lb. Okres: 1807-1847}

Jeszcze przed decyzjami z 1798 r., reorganizującymi strukturę diecezji łacińskich na obszarze państwa rosyjskiego, rząd wydał rozporządzenie dotyczące dostosowania granic dekanatów włączonych diecezji do podziałów administracji państwowej - powiatów (ujezdy) ${ }^{74}$. Śledzenie zmian w liczbie dekanatów przy częstych przesunięciach granic diecezji oraz braku jednolitego wykazu dla całej metropolii mohylewskiej z pierwszej połowy XIX w. utrudnia badania porównawcze. Wymagają one szczegółowych studiów źródłowych w celu przygotowania szeregu zestawień o charakterze kartograficzno-tabelarycznym. Zbiorczą statystykę, niestety bez podania podstawy źródłowej, przedstawił $\mathrm{w}$ przedwojennej pracy Jan Wasilewski. Tuż przed reorganizacją metropolii, związaną z konkordatem 1847 r., miało się w niej znajdować 94 dekanaty oraz 1038 parafii $(1846 \text { r. })^{75}$. Odnosząc to do statystyki z początku XIX w., oznaczałoby to wzrost liczby parafii w skali całej metropolii o 4,4\%. Należy brać pod uwagę, że jednym z czynników, który wpłynął na większą liczbę parafii, było włączenie w granice archidiecezji mohylewskiej nowych obszarów, jak chociażby okręg białostocki (1807) czy Finlandia $(1809)^{76}$.

Najpełniejsze informacje o zmianach dekanalnych, głównie dzięki studiom Skarbka ${ }^{77}$ oraz Tadeusza Krahela ${ }^{78}$, są dostępne dla diecezji wileńskiej. Skarbek ustalił sieć dekanatów tej diecezji w kilku przekrojach czasowych (przedstawienia tabelaryczne i kartograficzne) ${ }^{79}: 1772$ (26), 1783 (23), 1800 (18), 1825 (22), 1829 (25). Schematyzmy z lat 1844 i 1845 uwiarygadniają zestawienie Wasilewskiego - w 1846 r., przed reformą administracyjną, diecezja wileńska osiągnęła liczbę 30 dekanatów (Wilno, Wilno powiat, Giedrojcie, Jezno, Lida, Merecz, Oszmiana, Pobojsk, Raduń, Święciany, Świr, Troki, Wiszniew, Grodno, Brześć Litewski, Kobryń, Prużana, Słonim, Wołkowysk, Kowno, Abele, Kupiszki, Jeziorosy (Nowoaleksandrowsk), Poniewież, Uciana, Wiłkomierz, Nowogródek, Stwołowicze (Stołowicze), Kurlandzki (Kuldyga), Semigalski [Iłłukszta]). Znaczący wzrost liczby dekanatów przy zmniejszającym się jednocześnie terytorium diecezji w pierwszej połowie XIX w. świadczy o dość intensywnej rozbudowie sieci dekanalnej ${ }^{80}$.

Odwrotny proces, tzn. konsolidację i łączenie dekanatów, można odnotować w archidiecezji mohylewskiej, przy czym niektóre kościoły, przede wszystkim

${ }^{74}$ B. Kumor, Ustrój i organizacja..., s. 549.

75 J. Wasilewski, Arcybiskupi i administratorowie archidiecezji mohylowskiej, Pińsk 1930, s. 20.

76 B. Kumor, Ustrój i organizacja..., s. 24; idem, Granice metropolii..., s. 181-182.

77 J. Skarbek, Organizacja parafialna $w$ diecezji wileńskiej..., s. 118-143.

78 T. Krahel, op. cit.

${ }^{79} \mathrm{~W}$ nawiasie podano liczbę dekanatów.

${ }^{80}$ J. Skarbek, Organizacja parafialna $w$ diecezji wileńskiej..., s. 140-141; J. Wasilewski, op. cit., s. 20; Directorium horarum canonicarum et missarum pro dioecesi Vilnensi in annum Domini 1845, Vilnae 1844; Directorium horarum canonicarum et missarum pro dioecesi Vilnensi in annum Domini 1846, Vilnae 1845. 
w azjatyckiej części diecezji, leżały poza strukturami dekanalnymi. Tam gdzie sieć kościołów katolickich była słabiej rozwinięta i występowały one rzadko, schematyzmy pierwszej połowy XIX w. posługiwały się podziałem na prefektury i gubernie. Niejasna struktura jednostek administracyjnych w źródłach utrudnia interpretację: oprócz trzech względnie trwałych jednostek o charakterze archidiakonatów podzielonych na dekanaty (Mohylew, Kijów, Białystok) kościoły w archidiecezji mohylewskiej były grupowane w dość swobodny sposób. Spis z 1803 r. podaje 30 dekanatów ${ }^{81}$, zaś z 1808 r. - 33 dekanaty oraz 2 terytoria nieobjęte strukturą

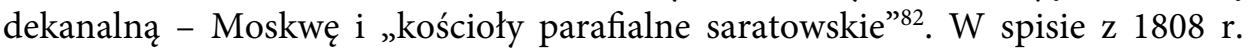
pojawiają się 3 dekanaty z tzw. archidiakonatu białostockiego: bielski, brański i drohiczyński. Zostały one określone jako „Kościoły Parafialne w Obwodzie Białostockim do Archi Dyecezyi Mohilewskiey przyłączone”. Trudne w jednoznacznej interpretacji jest pominięcie północnej części obwodu białostockiego (na północ od rzeki Narew), gdzie znajdowały się dekanaty sokólski, białostocki i knyszyński. Może to wynikać z zawiłych relacji terytorialnych między diecezją wigierską a mohylewską w okresie po pokoju tylżyckim ${ }^{83}$. Bardziej zróżnicowaną strukturę archidiecezji mohylewskiej zawiera schematyzm z 1820 r., który oprócz 31 dekanatów wymienia 10 prefektur ${ }^{84}$. Prawdopodobnie jeszcze przed reformą administracyjną z 1847 r. liczba dekanatów archidiecezji mohylewskiej została znacznie zredukowana - schematyzm archidiecezji mohylewskiej z 1848 r., obejmujący zasięgiem terytorium archidiecezji sprzed konkordatu, porządkuje kościoły parafialne, filialne oraz kaplice w 20 jednostkach: 15 dekanatów położonych w 4 guberniach (gub. mohylewska - dek. mohylewski, orszański, czausowski; gub. witebska - dek. witebski, lepelski, lucyński, rzeczycki, dyneburski, siebiesko-drysieński; gub. grodzieńska - dek. białostocki, sokólski, bielski; gub. kijowska - dek. wasylkowsko-radomyski, skwirsko-lipowiecki, humańsko-zwinogródzki), dekanaty petersburski oraz moskiewski, gubernia saratowska (podzielona dodatkowo między ujezdy-powiaty: kamaszyński, nowouzjeński, nikołajewski), gubernia chersońska oraz pozostałe kościoły parafialne i kaplice położone „in variis urbibus gubernialibus"85.

Trwałą i niezmienną strukturę dekanalną w pierwszej połowie XIX w. posiadała diecezja kamieniecka. W dość zgodnych ujęciach, zarówno w literaturze przedmiotu, jak i w świetle źródeł, składała się ona z 10 dekanatów: Bałta, Bracław, Jampol, Latyczów, Lityń, Mohylów n. Dniestrem, Płoskirów, Uszyca, Winnica, Zińkowce. Kamieniec Podolski jako stolicę diecezji traktowano odrębnie (niekiedy jako samodzielny dekanat) i nie był zaliczany do żadnej z wymienionych

81 Directorium... Mohyloviensis... 1803...

82 Spisek... mohilewskiey... 1808..., s. 9-21.

${ }^{83}$ B. Kumor, Granice metropolii..., s. 234-235.

${ }^{84}$ Directorium... Mohiloviensis... 1820...

${ }^{85}$ Directorium horarum canonicarum et missarum ad usum utriusque cleri archidioecesis Mohileviensis, Petropoli 1848, s. 106-116. Por. B. Kumor, Ustrój i organizacja..., s. 550. 
jednostek, tak jak kościoły w Besarabii ${ }^{86}$. Podobnie stabilną strukturę dekanalną posiadała diecezja łucko-żytomierska. Zgodnie z relacją bpa Cieciszowskiego z 1803 r. miała być ona podzielona na 12 dekanatów ${ }^{87}$. Dokładnie taką samą liczbę przedstawia schematyzm diecezji z 1843 r. (Łuck, Dubno, Włodzimierz, Kowel, Ostrog, Równe, Zasław, Stary Konstantynów, Nowogród Wołyński, Krzemieniec, Żytomierz, Owrucz $)^{88}$. Istnieją pewne wątpliwości odnośnie do dokładnej liczby dekanatów w diecezji mińskiej. Można przypuszczać, że różnice wynikały z różnego sposobu rejestracji dekanatów mińskiego i wilejskiego. Prawdopodobnie nie od samego początku istnienia diecezji, jak zakładał Kumor, była ona podzielona na 13 dekanatów ${ }^{89}$. Według spisu z 1800 r. diecezja miała się składać z 11 dekanatów ${ }^{90}$, zaś relacja bpa Cieciszowskiego z 1803 r. mówi o 12 dekanatach $^{91}$. Bardzo cenne jest opublikowane przez Radwana opracowanie Ignacego Borejki Chodźki, które choć wydane w 1845 r., przedstawia stan diecezji mińskiej na rok 1830. Porównanie tego zestawienia ze schematyzmem z 1842 r. wskazuje, że Chodźko połączył ze sobą 3 dekanaty „mińskie” i 2 dekanaty „wilejskie”. Stąd konkluzja wydawcy, że „struktury duszpasterskie tworzyło dziesięć dekanatów"92. Wspomniany schematyzm z 1842 r. wymienia 13 dekanatów: miński - miasto, miński - powiat, nadniemeński, ihumeński, bobrujski, piński, mozyrski, rzeczycki, borysowski, dziśnieński, wilejski, nadwilejski, słucki ${ }^{93}$. Struktura terytorialna diecezji żmudzkiej także nie uległa większym zmianom w pierwszej połowie XIX w. Do 10 dekanatów, które pozostały z diecezji przedrozbiorowej, doszedł na początku XIX w. dekanat w Botokach.

86 B. Kumor, Ustrój i organizacja..., s. 552; Directorium... Camenecensis... 1817...; Directorium divini officii dioecesis Camenecensis Podoliae ac ecclesiarum in Bessarabia in annum Domini 1847 sede vacante editum, Vilnae 1847, http://www.petergen.com/bovkalo/sp/camenec1847.html (dostęp: 15.02.2016); Directorium officii divini dioecesis Camenecensis Podoliae ac ecclesiarum in Bessarabia in annum Domini 1846, Cameneci 1845; Directorium officii divini dioecesis Camenecensis Podoliae ac ecclesiarum in Bessarabia in annum Domini 1845, Cameneci 1844.

87 Directorium divini officii ac missarum ad usum dioecesis Luceoriensis pro anno bissextili 1808, Luceoriae [b.d.w.]; Relationes status dioecesium in Magno Ducatu Lituaniae..., t. 2, s. 275.

${ }^{88}$ Kumor na podstawie procesów informacyjnych biskupów podaje, że w $1825 \mathrm{r}$. w diecezji było 10 dekanatów, zaś dekanat starokonstantynowski powstał między 1825 i 1842 r. W opracowaniach pomijany jest także dekanat w Nowogrodzie Wołyńskim, wymieniony przez schematyzmy z połowy XIX w., Directorium officii divini pro dioecesi Luceoriensis in annum Domini 1843, http:// www.petergen.com/bovkalo/sp/luck1843.html (dostęp: 15.02.2015); Directorium officii divini ac missarum ad usum dioecesis Luceoriensis pro anno Domini 1850, Vilnae 1849; B. Kumor, Ustrój i organizacja..., s. 551-552; Źródła do dziejów rozgraniczenia diecezji..., s. 182.

89 B. Kumor, Ustrój i organizacja..., s. 552.

90 W.A. Sułkowski, Kartka $z$ dziejów Kościoła katolickiego w Rosyi. Biskupstwo mińskie, Kraków 1889, s. 15.

91 Relationes status dioecesium in Magno Ducatu Lituaniae..., t. 2, s. 447.

92 I. Chodźko, Diecezja mińska około 1830 roku, t. 1: Struktury parafialne, wyd. M. Radwan, Lublin 1998 (Materiały do Dziejów Kościoła Katolickiego w Rzeczypospolitej i w Rosji, t. 5-6), s. 9 (dalej: Diecezja mińska około 1830 roku).

93 Directorium officii divini pro dioecesi Minscensi in annum Domini 1843, http://www.petergen. com/bovkalo/sp/minsk1843.html (dostęp: 16.02.2016). 
Zestawienie kościołów parafialnych, przygotowane przez Prašmantaitė na podstawie wizytacji generalnej z lat 1820-1821, wprowadza podział na 11 dekanatów: Olsiady, Botoki, Janiszki, Kroki, Retów, Wornie, Wielona, Wieksznie, Szkudy, Szadów, Szydłów ${ }^{94}$. Podobnie strukturę terytorialną diecezji żmudzkiej przedstawia schematyzm z $1843 \mathrm{r}^{95}$

Powyższy przegląd wskazuje, że istotne zmiany w sieci dekanalnej w pierwszej połowie XIX w. zaszły w archidiecezjach mohylewskiej (konsolidacja i zmniejszenie liczby dekanatów) oraz wileńskiej (rozdrobnienie i zwiększenie liczby dekanatów). Pozostałe diecezje zachowały względną stabilność pod tym względem. Zestawienie oparte na danych szczegółowych potwierdza w zasadzie liczbę dekanatów podaną w poszczególnych diecezjach przez Wasilewskiego na ok. 1846 r. ${ }^{96}$ Skarbek w monograficznym artykule poświęconym diecezji wileńskiej w XIX w. reorganizacje dekanalne przypisuje chęci „usprawnienia administracji kościelnej i duszpasterstwa w diecezji" ${ }^{97}$. Powstaje ponadto kwestia określenia relacji między rozwojem sieci dekanalnej i sieci parafialnej oraz wpływu reform administracji państwowej na strukturę dekanalną.

Ocena rozwoju sieci parafialnej w pierwszej połowie XIX w. w skali całej metropolii jest w znacznym stopniu utrudniona ze względu na brak odpowiednich wykazów z tego okresu dla diecezji wileńskiej ${ }^{98}$ oraz żmudzkiej ${ }^{99}$. Stąd ustalenie sumarycznej liczby kościołów parafialnych w jednym przedziale czasowym musi być obarczone pewnym błędem statystycznym. Duże uproszczenie stanowią zestawienia tabelaryczne Kumora dla poszczególnych diecezji, gdyż autor porównuje liczbę parafii w granicach diecezji, które ulegały zmianom, zwłaszcza po konkordacie $1847 \mathrm{r}$. i reorganizacji struktur terytorialnych Kościoła łacińskiego w Rosji ${ }^{100}$. Dość wiarygodne w świetle badań porównawczych są liczby wskazane przez Wasilewskiego dla połowy XIX w., a więc przed reorganizacją. Schematyzm diecezji mohylewskiej z 1848 r. podaje liczbę 295 kościołów parafialnych (Wasilewski - 288) ${ }^{101}$,

94 A. Prašmantaitè, op. cit., s. 103-104, 123-127.

95 Directorium horarum canonicarum et missarum pro dioecesi Telsensi in annum Domini 1843, Vilnae 1842.

96 Liczba dekanatów dla diecezji kamienieckiej wyniosła 10, a nie jak w pracy Wasilewskiego - 11. Potraktował on prawdopodobnie kościoły w stolicy diecezji, Kamieńcu Podolskim, jako odrębny dekanat. J. Wasilewski, op. cit., s. 20.

97 J. Skarbek, Organizacja parafialna $w$ diecezji wileńskiej..., s. 140.

98 Informacje dotyczące parafii w schematyzmach wileńskich pojawiają stosunkowo późno, dopiero w 1851 r. występuje pierwszy wykaz kościołów parafialnych, filialnych i kaplic. T. Krahel, op. cit., s. 31.

99 Pierwsza informacja o kościołach parafialnych i ich przynależności dekanalnej pojawia się w schematyzmie diecezji żmudzkiej (telszewskiej) na rok 1854, S. Librowski, Katalog rubrycel i schematyzmów diecezji i zakonów historycznej Polski znajdujących się $w$ księgozbiorze podręcznym Archiwum Diecezjalnego we Włocławku: cz. 1. Rubrycele i schematyzmy diecezjalne, z. 4. Archidiecezja warszawska - diecezja żmudzka, „Archiwa, Biblioteki i Muzea Kościelne” 26 (1973), s. 182.

100 B. Kumor, Ustrój i organizacja..., s. 672-681.

101 Directorium... Mohileviensis... 1848..., s. 106-116. 
Tabela 3. Liczba dekanatów i kościołów w diecezjach metropolii mohylewskiej ok. 1846 r. (przed reorganizacją pokonkordatową, z odniesieniem do liczby parafii z początku XIX w.)

\begin{tabular}{|c|c|c|c|c|c|c|c|c|}
\hline \multirow{3}{*}{ Nazwa diecezji } & \multicolumn{2}{|c|}{ Liczba dekanatów } & \multicolumn{6}{|c|}{ Liczba kościołów } \\
\hline & \multirow{2}{*}{ ok. $1846 r^{102}$} & \multirow{2}{*}{$\begin{array}{c}\text { na początku } \\
\text { XIX w. }{ }^{103}\end{array}$} & \multirow{2}{*}{$\begin{array}{l}\text { parafialnych } \\
\text { ok. } 1846 r^{104}\end{array}$} & \multicolumn{3}{|c|}{ w 1834 r. (bez świątyń zakonnych) ${ }^{105}$} & \multirow{2}{*}{$\begin{array}{l}\text { parafialnych } \\
\text { ok. } 1803 \text { r. }{ }^{106}\end{array}$} & \multirow{2}{*}{$\begin{array}{c}\text { zmiana } \\
\text { procentowa }\end{array}$} \\
\hline & & & & parafialne & pomocnicze & kaplice & & \\
\hline mohylewska & 17 & 36 & 288 & 254 & 90 & 409 & 274 & 5,1 \\
\hline wileńska & 30 & 18 & 318 & 299 & 59 & 209 & 317 & 0,3 \\
\hline żmudzka & 11 & 11 & 119 & 105 & 59 & 92 & 105 & 13,3 \\
\hline łucko-żytomierska & 12 & 12 & 113 & 87 & 6 & 125 & 117 & $-3,4$ \\
\hline kamieniecka & 10 & 10 & 106 & 81 & 3 & 54 & 81 & 30,9 \\
\hline mińska & 13 & 11 & 94 & 91 & 48 & 174 & 100 & $-6,0$ \\
\hline RAZEM & 93 & 98 & 1038 & 917 & 265 & 1063 & 994 & 4,4 \\
\hline
\end{tabular}

102 Podstawa informacji: J. Wasilewski, op. cit., s. 20; Directorium... Mohileviensis... 1848..., s. 107; Directorium... Vilnensi... 1846...; Directorium... Telsensi... 1843...; Directorium... Luceoriensis... 1843...; Directorium... Camenecensis... 1846..., s. 109-115; Directorium... Minscensi... 1843...

103 Podstawa informacji: Spisek... mohilewskiey... 1808..., s. 9; Directorium... Luceoriensis... 1808...; Directorium... Camenecensis... 1817...; W.A. Sułkowski, Kartka z dziejów Kościoła katolickiego $w$ Rosyi..., s. 15; A. Prašmantaitė, op. cit., s. 105; J. Skarbek, Organizacja parafialna w diecezji wileńskiej..., s. 140; B. Kumor, Ustrój i organizacja..., s. 551-552 (diec. łucka - 1825 r.; diec. kamieniecka - 1815 r.).

104 J. Wasilewski, op. cit., s. 20.

105 Die neuesten Zustände der katholishen Kirche..., s. 373.

106 Zob. tabela 2. 
dla diecezji łuckiej schematyzm z 1843 r. wskazuje liczbę 109, z 1845 r. - 113 parafii (Wasilewski - 113) ${ }^{107}$, dla diecezji kamienieckiej schematyzm z $1845 \mathrm{r}$. podaje liczbę 103 parafii (Wasilewski - 106) ${ }^{108}$, zaś dla diecezji mińskiej schematyzm z 1843 r. wskazuje 96 parafii (Wasilewski - 94) ${ }^{109}$. Dodatkowo wiarygodność statystyki z tabeli Wasilewskiego wzmacniają dane z $1834 \mathrm{r} .{ }^{110}$

Na podstawie porównania liczby parafii z początku oraz ostatniej dekady pierwszej połowy XIX w. widać, że rozwój sieci parafialnej nie przebiegał w sposób równomierny. W skali całej metropolii wzrost ten wyniósł ok. 4,4\%. Najintensywniej pod względem struktury parafialnej rozwijały się obszary metropolii wysunięte najbardziej na południe (diecezja kamieniecka) oraz na północ (diecezja żmudzka). Pozostałe diecezje zachowały $\mathrm{z}$ niewielkimi odchyleniami (-6\% do 5,1\%) liczbę parafii z początku XIX w. Względnie stabilna liczba parafii diecezji wileńskiej, łucko-żytomierskiej, mińskiej i mohylewskiej nie oznacza braku zmian w analizowanym okresie. Miały one wymiar regionalny i dotyczyły zarówno likwidacji części parafii (szczególnie zakonnych związanych z kasatami klasztorów po 1832 r.), jak też powstawania nowych ośrodków duszpasterskich.

\section{Okres 1847-1914}

Druga połowa XIX w. to czas ważnych zmian organizacyjnych na poziomie diecezjalnym. Na skutek reorganizacji po konkordacie 1847 r. diecezje „zamknięto” w granicach guberni ${ }^{111}$. W latach $1847-1848$ została zorganizowana diecezja chersońska (tyraspolska), wyodrębniona z części terytorium archidiecezji mohylewskiej - namiestnictwo kaukaskie, gubernie krymska (taurydzka), jekaterynosławska, chersońska, saratowska, południowe powiaty guberni samarskiej (Mikołajów i Nowouzeńsk), gubernie astrachańska i stawropolska, a także kamienieckiej obwód besarabski ${ }^{112}$. W tym samym czasie, po konkordacie, archidiecezja mohylewska utraciła gubernię kijowską (dekanaty wasylkowsko-radomyski, skwirsko-lipowiecki, humańsko-zwinogródzki) na rzecz diecezji łucko-żytomierskiej oraz gubernię grodzieńską (dekanaty białostocki, sokólski, bielski) na rzecz diecezji wileńskiej. W ramach dostosowania granic diecezji do granic gubernialnych przesunięcia nastąpiły także między diecezją wileńską a diecezjami mińską i żmudzką ${ }^{113}$. Kolejne

107 Directorium... Luceoriensis... 1843...; Directorium horarum canonicarum et missarum pro dioecesi Luceoriensi in annum Domini 1846, Vilnae 1845.

108 Directorium... Camenecensis... 1846..., s. 109-115.

109 Directorium... Minscensi... 1843...

110 Die neuesten Zustände der katholishen Kirche..., s. 373.

111 Źródła do dziejów rozgraniczenia diecezji..., s. XVIII.

112 J. Schnurr, Die Kirchen und das religiöse Leben der Russlanddeutschen. Katholischer Teil: Aus Vergangenheit und Gegenwart des Katholizismus in Rußland, Stuttgart 1980, s. 48.

113 Diecezja wileńska utraciła na rzecz diecezji żmudzkiej dekanaty wiłkomierski i kupicki (Kupiszki) oraz częściowo dekanaty kowieński, upicki i brasławski i Kurlandię. Z kolei na rzecz diecezji 
zmiany przyszły po powstaniu styczniowym - 2 diecezje utraciły pełnię praw i uzyskały status administratur apostolskich. Diecezja mińska została w 1869 r. podporządkowana diecezji wileńskiej, aby ostatecznie w 1880 r. trafić pod zarząd arcybiskupa mohylewskiego ${ }^{114}$. Z kolei diecezja kamieniecka w 1867 r. faktycznie, zaś w $1880 \mathrm{r}$. formalnie, została podporządkowana biskupowi łucko-żytomierskiemu ${ }^{115}$. W ten sposób ukształtowała się struktura metropolii mohylewskiej, w skład której wchodziło 5 diecezji (archidiecezja mohylewska, diecezje: wileńska, żmudzka, łucko-żytomierska i tyraspolska) oraz 2 administratury apostolskie (kamieniecka i mińska).

Przytoczone zmiany wpłynęły zarówno na liczbę dekanatów, jak i parafii w poszczególnych diecezjach. Praktycznie bez zmian w strukturze dekanalnej przetrwała do I wojny światowej tylko diecezja kamieniecka (od 1880 r. administratura apostolska). Wykazy świątyń z 1867 i 1914 r. wskazują, że dekanat Zińkowce w drugiej połowie XIX w., po włączeniu do niego kościołów położonych w stolicy diecezji, przyjął nazwę dekanat kamieniecki ${ }^{116}$. Liczba dekanatów w diecezji łucko-żytomierskiej wzrosła wyraźnie, ale nie był to skutek rozwoju sieci dekanalnej, ale wynik włączenia po 1847 r. 3 dekanatów, należących wcześniej do archidiecezji mohylewskiej (wasylkowsko-radomyski, skwirsko-lipowiecki, humańsko-zwinogródzki), które w następnych latach zostały rozdzielone na 6 jednostek. W 1914 r. w tej części diecezji łucko-żytomierskiej (gubernia kijowska) znajdowały się: dekanat kijowski (wcześniej wasylkowski lub wasylkowsko-kijowski ${ }^{117}$ ), berdyczowski (w schematyzmie „Lipowiec-Berdyczowiensis”), radomyski, skwirski, humański i zwinogródzki. Stabilna była część wołyńska diecezji łucko-żytomierskiej - wątpliwości może budzić jedynie sytuacja dekanatu z siedzibą w Nowogrodzie Wołyńskim ${ }^{118}$, który pojawia się w sposób nieregularny, oraz dekanatów Zasław i Ostróg, które traktowano od początku XX w. jako jeden dekanat ${ }^{119}$. W sumie

mińskiej diecezja wileńska straciła dekanat nowogrodzki, zaś uzyskała w to miejsce dekanat radoszkowicki i częściowo połocki, B. Kumor, Granice metropolii..., s. 182.

114 J. Skarbek, Kościół rzymskokatolicki na Białorusi..., s. 27.

115 B. Kumor, Granice metropolii..., s. 186.

116 Elenchus cleri secularis dioeceseos Luceoriensis et Żytomiriensis ordine alphabetico confectus 1876, [Vilna b.d.w.]; Elenchus omnium ecclesiarum et universi cleri dioecesium Luceoriensis et Żytomiriensis nec non Camenecensis anno Domini 1914, [Żytomiria b.d.w.].

117 Określenie „dekanat Kijowski” pojawia się w spisie z 1808 r., zaś „decanatus Kijoviensis et Vasilkoviensis" - w schematyzmie z 1820 r., Spisek... mohilewskiey... 1808...; Directorium... Mohiloviensis... 1820...

118 Dekanat Nowogród Wołyński (Zwiahel) jest rejestrowany przez schematyzmy z 1842, 1849, 1902, 1914 r. Nie występuje w latach 1876, 1894, sam zaś Nowogród Wołyński należy do dekanatu Równe. Podobnie sprawę przedstawił Skarbek na mapie diecezji łucko-żytomierskiej w 1855 r., Directorium... Luceoriensis... 1843...; Directorium... Luceoriensis... 1850...; Dioeceses Luceoriensis et Żytomiriensis nec non ecclesiae per Podoliam anno Domini 1902, [Żytomiria b.d.w.], s. 51-52; Elenchus... Luceoriensis... 1914..., s. 129-130; Elenchus... Luceoriensis... 1876..., s. 24-27; Dioeceses Luceoriensis et Żytomiriensis nec non ecclesiae per Podoliam Anno 1894, [Żytomiria b.d.w.], s. 47-49; Źródła do dziejów rozgraniczenia diecezji..., mapa: Diecezja łucko-żytomierska w 1855 r.

119 Dioeceses Luceoriensis... 1894..., s. 49-51; Dioeceses Luceoriensis... 1902..., s. 54-55; Elenchus... Luceoriensis... 1914..., s. 131-132. 
schematyzm diecezji łucko-żytomierskiej z 1914 r., oprócz 10 dekanatów w administrowanej diecezji kamienieckiej i 6 dekanatów w guberni kijowskiej, podaje 11 dekanatów należących do guberni wołyńskiej ${ }^{120}$.

Pomniejszona terytorialnie po reformie administracyjnej z 1847 r. diecezja wileńska liczyła w drugiej połowie XIX w. 23 dekanaty ${ }^{121}$. Na skutek przesunięć granicznych przeszły do diecezji żmudzkiej w całości lub częściowo dekanaty: Jeziorosy-Nowoaleksandrowsk (Brasław), Poniewież (wcześniej Upita), Abele, Kowno, Wiłkomierz, Uciana, kurlandzki (Kuldyga) i semigalski (Iłłukszta). Dekanaty Kupiszki i Pobojsk zostały zlikwidowane - miejscowość Kupiszki znajdowała się w 1914 r. w dekanacie Uciana, zaś Pobojsk w dekanacie Wiłkomierz (diecezja żmudzka). Jezno pozostało w diecezji wileńskiej, ale przestało być stolicą dekanatu - schematyzm diecezji wileńskiej z 1914 r. lokuje tę parafię w dekanacie Merecz. Do diecezji mińskiej przeszły dekanaty Nowogródek i Stwołowicze. Do pozostałych w diecezji wileńskiej 17 dekanatów (Wilno, Wilno powiat, Giedrojcie, Lida, Merecz, Oszmiana, Raduń, Święciany, Świr, Troki, Wiszniew, Grodno, Brześć Litewski, Kobryń, Prużana, Słonim, Wołkowysk) na skutek zmian granic diecezji dołączyły 3 dekanaty z archidiecezji mohylewskiej (Białystok, Bielsk, Sokółka) oraz 3 z diecezji mińskiej (Dzisna, Nadwilejka, Wilejka) ${ }^{122}$.

Zmniejszenie liczby dekanatów w diecezji wileńskiej i wzrost ich liczby w diecezji żmudzkiej (w drugiej połowie XIX w. określanej jako telszańska) wynikały ze zmiany granic diecezji. Do istniejących wcześniej 11 dekanatów żmudzkich dołączono 8 „wileńskich”. W ten sposób diecezja żmudzka w 1914 r. składała się z 19 dekanatów: Kowno, Kroki, Wielona, Wiłkomierz, Uciana, Abele, Jeziorosy-Nowoaleksandrowsk (Brasław), Poniewież (wcześniej Upita), Janiszki, Wieksznie, Szadów, Olsiady, Szkudy, Wornie, Botoki, Retów, Szydłów, semigalski (Iłłukszta), kurlandzki (Kuldyga) ${ }^{123}$. Na skutek modyfikacji granicy między diecezją mińską i wileńską $\mathrm{w}$ połowie XIX w. uległa zmianie także liczba dekanatów w diecezji mińskiej. Utraciła ona 3 dekanaty (Dzisna, Nadwilejka, Wilejka), natomiast uzyskała 2 (Nowogródek, Stwołowicze) ${ }^{124}$. W drugiej połowie XIX w. liczba dekanatów w diecezji mińskiej, w znacznym stopniu na skutek likwidacji parafii, zmalała: zostały połączone dekanaty miński miejski i powiatowy, dekanat mozyrski z rzeczyckim, zaś większość parafii dekanatu Stwołowicze znalazła się w dekanacie Nowogródek. W 1914 r. diecezja mińska była podzielona na 9 dekanatów: miński, nadniemeński, borysowski, ihumeński, bobrujski, mozyrsko-rzeczycki, piński, słucki, nowogródzki ${ }^{125}$.

120 Elenchus... Luceoriensis... 1914...

121 J. Skarbek, Organizacja parafialna $w$ diecezji wileńskiej..., s. 141.

122 Calendarium pro clero dioecesis Vilnensis in annum Domini 1914, Vilnae 1913, s. 229-281.

123 Ordo divini officii et missarum ad usum Samogitiensis seu Telsensis dioecesis pro anno Domini 1914, Seinis 1914, s. 22.

124 J. Skarbek, Organizacja parafialna $w$ diecezji wileńskiej..., s. 120.

125 Directorium divini officii et missarum pro archidioecesi Mohyloviensi nec non pro dioecesi Minscensi in annum Domini 1914, [b.m.d.w.], s. 197-211; B. Kumor, Ustrój i organizacja..., s. 555. 
Najpoważniejsze i jednocześnie najtrudniejsze w rejestracji zmiany zaszły w administracji dekanalnej archidiecezji mohylewskiej i wyodrębnionej z niej (oraz częściowo z diecezji kamienieckiej) diecezji tyraspolskiej. Archidiecezja mohylewska straciła po $1847 \mathrm{r}$. dobrze zorganizowane pod względem administracji terytorialnej gubernie grodzieńską (na rzecz diecezji wileńskiej) oraz kijowską (na rzecz diecezji łucko-żytomierskiej), a także gubernie południowe, gdzie ukonstytuowała się diecezja tyraspolska. W drugiej połowie XIX w. dokonała się więc faktyczna przebudowa organizacji dekanalnej na rozległych obszarach tej największej w świecie diecezji rzymskokatolickiej. Można przy tym dostrzec wyraźne nawiązanie do bardziej rozbudowanej struktury dekanatów, obowiązującej jeszcze w trzeciej dekadzie XIX w. (przed zmniejszeniem ich liczby w latach czterdziestych, przed reorganizacją metropolii mohylewskiej) - zob. tabela $4^{126}$. Towarzyszyła temu także zmiana nazewnictwa istniejących już jednostek, które często przybierały nazwę dwuczłonową. Schematyzm z 1914 r. mówi o 23 dekanatach oraz 22 kościołach parafialnych wyłączonych ze struktury dekanalnej, położonych we wschodniej części archidiecezji.

Podobnie jak w archidiecezji mohylewskiej, złożone i dynamiczne były losy sieci dekanatów diecezji tyraspolskiej. Na obszarze tym, w czasie jego przynależności do archidiecezji mohylewskiej i diecezji kamienieckiej, nie rozwinęła się struktura dekanalna. Pierwszy znany schematyzm tej diecezji z $1853 \mathrm{r}$. podaje informację o 4 dekanatach-wizytatorstwach: chersońskim, saratowskim, kaukaskim i zakaukaskim (przy czym ostatni składał się tylko ze świątyń obrządku ormiańskiego) ${ }^{127}$. Należy tutaj dodać, że do struktur diecezji tyraspolskiej obrządku łacińskiego zaliczane były także kościoły katolickie obrządku ormiańskiego aż do momentu utworzenia administratury ormiańsko-katolickiej dla Rosji $(1909)^{128}$. Struktura terytorialna tej diecezji rozwijała się systematycznie w drugiej połowie XIX w. - w 1865 r. było 8 dekanatów łacińskich: saratowski, samarski, jekaterynosławski, taurydzki, chersoński, besarabski, kaukaski i zakaukaski, przy czym 2 ostatnie dekanaty traktowano łącznie jako jedno wizytatorstwo ${ }^{129}$.

126 B. Kumor, Ustrój i organizacja..., s. 554.

127 Directorium seu ordo divini officii recitandi missaeque celebrandae ab utroque clero dioecesis Chersonensis in annum Domini 1853, Odessae [b.d.w.], s. 107-114; Б. Кумор, Российский конкордат и создание Тираспольской епархии, http://catholichurch.ru/index.php/files/file/155-кумор-броссийский-конкордат-и-создание-тирасп/ (dostęp: 8.03.2016).

128 J. Schnurr, op. cit., s. 20.

129 Directorium officii divini pro dioecesi Tiraspolensi in annum Domini 1866, http://www.petergen. com/bovkalo/sp/tyraspol1866.html (dostęp: 8.03.2016). Trudno stwierdzić, na jakiej podstawie Olga Litzenberger podała informację, że diecezja składała się w 1865 r. z 4 dekanatów oraz wizytatorstwa kaukasko-zakaukaskiego, О.А. Лиценбергер, Римско-католическая Церковь в России: история и правовое положение, Саратов 2001, s. 109; S. Librowski, Katalog rubrycel i schematyzmów diecezji i zakonów historycznej Polski znajdujących się w księgozbiorze podręcznym Archiwum Diecezjalnego we Włocławku: cz. 1. Rubrycele i schematyzmy diecezjalne, z. 3. Diecezja podlaska - diecezja warmińska, „Archiwa, Biblioteki i Muzea Kościelne” 25 (1972), s. 96-97. 


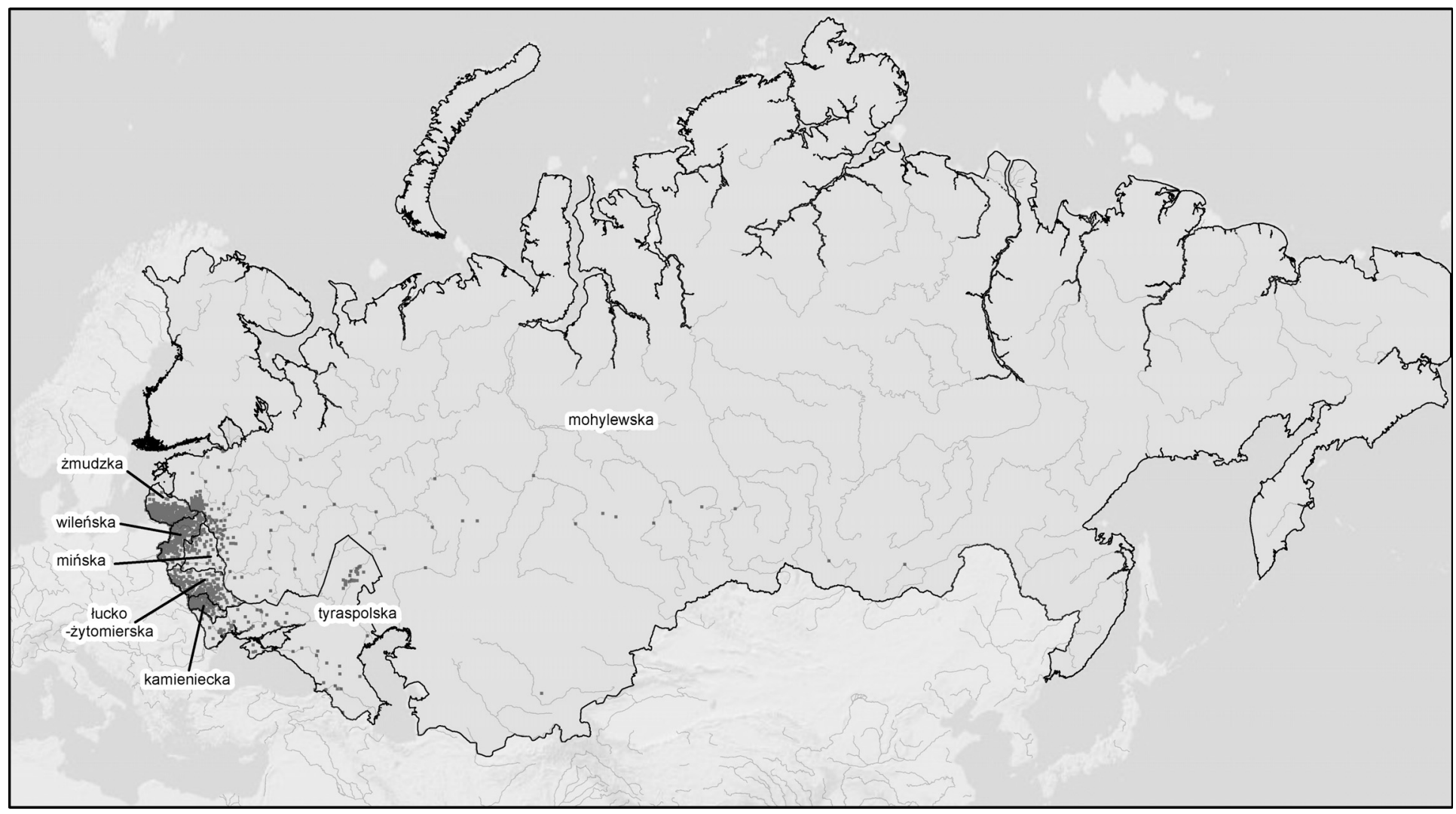

Rycina 2. Podział metropolii mohylewskiej na diecezje ok. 1914 r. Mapa bazowa: ESRI World Shaded Relief, http://services.arcgisonline.com/ArcGIS/services. 
Tabela 4. Dekanaty w archidiecezji mohylewskiej w XIX w. ${ }^{130}$

\begin{tabular}{|c|c|c|c|c|c|}
\hline 1803 & $1808^{131}$ & $1820^{132}$ & $1848^{133}$ & $1880^{134}$ & $1914^{135}$ \\
\hline petersburski & petersburski & petersburski & petersburski & petersburski & petersburski \\
\hline mohylewski & mohylewski & mohylewski & mohylewski & mohylewsko-horecki & mohylewsko-horecki \\
\hline \multirow{2}{*}{ rohaczewski } & bychowski & \multirow{2}{*}{ bychowski } & \multirow{2}{*}{ [mohylewski] } & \multirow{2}{*}{ rohaczewsko-bychowski } & \multirow{2}{*}{ rohaczewsko-bychowski } \\
\hline & rohaczewski & & & & \\
\hline bielicki & bielicki & bielicki & [mohylewski] & homelsko-bielicki & homelski \\
\hline mścisławski & mścisławski & klimowicko-mścisławski & [czausowski] & klimowicko-mścisławski & klimowicko-mścisławski \\
\hline czausowski & czerykowsko-czausowski & czerykowsko-czausowski & czausowski & czerykowsko-czausowski & czerykowsko-czausowski \\
\hline orszański & orszańsko-smoleński & orszański & orszański & orszański & orszański \\
\hline \multirow{2}{*}{ sienneński } & sienneński & sienneński & [orszański] & sienneński & sienneński \\
\hline & babinowicki & \multirow{2}{*}{ witebsko-babinowicki } & [orszański] & [orszański] & [orszański] \\
\hline \multirow{2}{*}{ witebski } & \multirow{2}{*}{$\begin{array}{l}\text { witebsko-wielisko- } \\
\text {-suraski }\end{array}$} & & witebski & \multirow{3}{*}{ witebski } & \multirow{3}{*}{ witebski } \\
\hline & & \multirow{2}{*}{ newelsko-wieliski } & [witebski] & & \\
\hline newelski & newelski & & [siebiesko-drysieński] & & \\
\hline połocki & połocki & połocki & [witebski] & połocki & połocki \\
\hline lepelski & lepelski & lepelski & lepelski & lepelski & lepelski \\
\hline siebieski & siebieski & siebieski & \multirow{2}{*}{ siebiesko-drysieński } & \multirow{2}{*}{ siebiesko-drysieński } & \multirow{2}{*}{ siebiesko-drysieński } \\
\hline drysieński & drysieński & drysieński & & & \\
\hline
\end{tabular}

${ }^{130}$ W nawiasie kwadratowym zaznaczono przynależność dekanalną stolic dekanatów, które zostały wymienione w innych przekrojach czasowych; pusty nawias kwadratowy oznacza, że stolica dekanatu z innego przekroju czasowego nie była objęta podziałem dekanalnym; myślnik wskazuje brak informacji o świątyni katolickiej w danym okresie dla stolicy dekanatu, który został wymieniony w innym przekroju czasowym.

131 Podstawa źródłowa: Spisek... mohilewskiey... 1808..., s. 9-21.

132 Directorium... Mohiloviensis... 1820...

133 Directorium... Mohileviensis... 1848..., s. 106-116.

134 W. Knapiński, Mohilewska archidiecezja i prowincja..., s. 540-542.

135 Directorium... Mohyloviensi... 1914..., s. 151-197. 
Tabela 4. Cd.

\begin{tabular}{|c|c|c|c|c|c|}
\hline 1803 & 1808 & 1820 & 1848 & 1880 & 1914 \\
\hline dyneburski górny & dyneburski górny & dyneburski górny & \multirow{2}{*}{ dyneburski } & dyneburski górny & dyneburski górny \\
\hline dyneburski dolny & dyneburski dolny & dyneburski dolny & & dyneburski dolny & dyneburski dolny \\
\hline rzeżycki nad Raźnem & rzeżycki nad Raźnem & \multirow{2}{*}{ rzeżycki } & \multirow{2}{*}{ rzeżycki } & rzeżycki nad Raźnem & rzeżycki nad Raźnem \\
\hline rzeżycki nad Łubaniem & rzeżycki nad Łubaniem & & & rzeżycki nad Łubaniem & rzeżycki nad Łubaniem \\
\hline zalucyński & zalucyński & \multirow{2}{*}{ lucyński } & \multirow{2}{*}{ lucyński } & zalucyński & zalucyński \\
\hline przedlucyński & przedlucyński & & & przedlucyński & przedlucyński \\
\hline [dyneburski dolny] & [dyneburski dolny] & [dyneburski dolny] & [] & [petersburski] & ryski \\
\hline moskiewski & [] & moskiewski & moskiewski & moskiewski & moskiewski \\
\hline- & - & [] & [] & [] & irkucki \\
\hline- & - & [] & [] & [] & tomski \\
\hline- & - & - & - & [] & omski \\
\hline armeński & astrachański & [] & [] & \multicolumn{2}{|l|}{ w diec. tyraspolskiej } \\
\hline saratowski & [] & [] & [] & \multicolumn{2}{|l|}{ w diec. tyraspolskiej } \\
\hline w diec. wigierskiej & bielski & bielski & bielski & \multicolumn{2}{|l|}{ w diec. wileńskiej } \\
\hline $\mathrm{w}$ diec. wigierskiej & brański & brański & [bielski] & \multicolumn{2}{|l|}{ w diec. wileńskiej } \\
\hline $\mathrm{w}$ diec. wigierskiej & drohiczyński & drohiczyński & [bielski] & \multicolumn{2}{|l|}{ w diec. wileńskiej } \\
\hline kijowski & kijowski & kijowsko-wasylkowski & \multirow{2}{*}{ wasylkowsko-radomyski } & \multirow{2}{*}{\multicolumn{2}{|c|}{ w diec. łucko-żytomierskiej }} \\
\hline radomyski & radomyski & radomyski & & & \\
\hline kopyski & kopyski & kopyski & [mohylewski] & \multicolumn{2}{|l|}{-} \\
\hline lipowiecki & lipowiecki & lipowiecko-machnowski & \multirow{2}{*}{ skwirsko-lipowiecki } & \multirow{2}{*}{\multicolumn{2}{|c|}{ w diec. łucko-żytomierskiej }} \\
\hline skwirski & skwirski & skwirsko-taraszczański & & & \\
\hline noworosyjski & noworosyjski & [] & [] & \multicolumn{2}{|l|}{ w diec. tyraspolskiej } \\
\hline zwinogrodzki & zwinogrodzki & zwinogrodzki & humańsko-zwinogrodzki & \multicolumn{2}{|l|}{ w diec. łucko-żytomierskiej } \\
\hline $\mathrm{w}$ diec. wigierskiej & w diec. wigierskiej & białostocki & \multirow{2}{*}{ białostocki } & \multirow{2}{*}{\multicolumn{2}{|c|}{ w diec. wileńskiej }} \\
\hline w diec. wigierskiej & w diec. wigierskiej & knyszyńki & & & \\
\hline w diec. wigierskiej & $\mathrm{w}$ diec. wigierskiej & sokólski & sokólski & \multicolumn{2}{|l|}{ w diec. wileńskiej } \\
\hline
\end{tabular}


Lata następne przyniosły wzrost liczby dekanatów, przy czym najintensywniejszy rozwój przypadł na okres od 1872 do 1874 r.: na skutek podziałów powstały wówczas 4 nowe dekanaty - dekanat samarski podzielił się na jekaterinensztadzki i równieński, dekanat taurydzki - na berdiański i symferopolski, dekanat chersoński - na nikołajewski i odeski, z dekanatu saratowskiego zaś wyodrębnił się dekanat kamieński ${ }^{136}$. W $1896 \mathrm{r}$. został zniesiony dekanat besarabski ${ }^{137}$, parafie do niego należące zaś włączono do dekanatu odeskiego. Według schematyzmu z $1914 \mathrm{r}$. diecezja dzieliła się na 9 dekanatów oraz wizytatorstwo kaukaskie i zakaukaskie ${ }^{138}$.

Sumaryczne zestawienie rozwoju katolickiej sieci parafialnej w Cesarstwie Rosyjskim w drugiej połowie XIX w. (tabela 5) wskazuje praktyczny brak zmiany liczby parafii na terenie metropolii mohylewskiej między 1853 i 1914 r. (wahała się ona w granicach błędu statystycznego). Obrazuje natomiast istotne różnice między poszczególnymi diecezjami, a także różną dynamikę rozwoju poszczególnych regionów w porównaniu z pierwszą połową tego stulecia. Archidiecezja mohylewska dzieliła się pod tym względem na dwie części - w tej objętej w połowie XIX w. strukturą dekanalną nastąpiły regres i upadek części kościołów parafialnych (ok. $15 \%)$, natomiast na terenach wschodnich, które weszły w XX w. w skład dekanatów syberyjskich (Omsk, Irkuck, Tomsk), oraz na obszarach określanych w $1914 \mathrm{r}$. jako „Russia Europea” i „Russia Asiatica”, nastąpił wyraźny wzrost zarówno liczby kościołów parafialnych, jak i świątyń filialnych, kaplic oraz oratoriów. Za zdecydowanie zawyżoną należy uznać liczbę kościołów parafialnych w archidiecezji mohylewskiej podaną w opracowaniu Kumora (na 1914 r.) ${ }^{139}$.

Pewne trudności w dokładnym ustaleniu liczby świątyń parafialnych wynikają $\mathrm{z}$ tego, że nie wszystkie schematyzmy diecezjalne precyzyjnie określają kategorie wymienianych kościołów. Najbardziej zbliżony czasowo do 1914 r. schematyzm diecezji wileńskiej, który dokonuje rozróżnienia między kościołami parafialnymi i pomocniczymi, pochodzi z $1911 \mathrm{r}$. i wspomina o 247 kościołach parafialnych ${ }^{140}$. Statystykę tę uwiarygadniają zestawienia zbiorcze z okresu kilka lat wcześniejszego - w 1905 r. w diecezji wileńskiej znajdowało się 237 kościołów parafialnych ${ }^{141}$.

${ }^{136}$ Na taki podział wskazuje analiza schematyzmów z lat 1866 i 1914 . Directorium... Tiraspolensi... $1866 . . . ;$ Directorium horarum canonicarum et sacrarum missarum ad usum dioecesis Tiraspolensis pro anno Domini 1914, Saratoviae 1913, s. 24-68.

137 S. Librowski, Katalog rubrycel i schematyzmów diecezji i zakonów historycznej Polski znajdujących się w księgozbiorze podręcznym Archiwum Diecezjalnego we Włocławku, cz. 1, z. 3..., s. 103; B. Kumor, Ustrój i organizacja..., s. 556.

138 Directorium... Tiraspolensis... 1914..., s. 59-60. Litzenberger informuje, że na początku XX w. diecezja tyraspolska składała się z 11 dekanatów. Wizytatorstwo kaukaskie i zakaukaskie traktuje jako dekanat piatyhorsko-tibiliski. Według Josepha Schnurra dekanat Mariental powstał dopiero po I wojnie światowej. О.А. Лиценбергер, Тираспольская епархия, w: Католическая энииклопедия, т. 4, Москва 2011, kol. 1339; J. Schnurr, op. cit., s. 264.

139 B. Kumor, Ustrój i organizacja..., s. 680.

140 Directorium... Vilnensi... 1912..., s. 17-83.

141 Directorium... Vilnensi... 1906..., s. 202. Według Schnurra w 1902 r. diecezja wileńska posiadała 245 kościołów parafialnych. J. Schnurr, op. cit., s. 24. Zob. też: T. Krahel, op. cit., s. 38. 
Tabela 5. Liczba dekanatów i kościołów parafialnych w diecezjach metropolii mohylewskiej ok. 1855 r. i w 1914 r.

\begin{tabular}{|c|c|c|c|c|c|c|}
\hline \multirow[t]{2}{*}{ Nazwa diecezji } & \multicolumn{2}{|c|}{ Liczba dekanatów } & \multicolumn{3}{|c|}{ Liczba kościołów parafialnych } & \multirow{2}{*}{$\begin{array}{l}\text { Zmiana procentowa w liczbie } \\
\text { parafii }(1853-1914)\end{array}$} \\
\hline & ok. 1855 & ok. 1914 & $1853^{142}$ & $1857^{143}$ & ok. 1914 & \\
\hline mohylewska $^{144}$ & 20 & 23 & 162 & 164 & 171 & 5,56 \\
\hline wileńska ${ }^{145}$ & 23 & 23 & 285 & 289 & 247 & $-13,33$ \\
\hline$\dot{z ̇ m u d z k a}^{146}$ & 19 & 19 & 203 & 213 & 219 & 7,88 \\
\hline łucko-żytomierska ${ }^{147}$ & 17 & 17 & 160 & 159 & 155 & $-3,13$ \\
\hline kamieniecka $^{148}$ & 10 & 10 & 99 & 99 & 97 & $-2,02$ \\
\hline mińska ${ }^{149}$ & 12 & 9 & 81 & 81 & 50 & $-38,27$ \\
\hline tyraspolska $^{150}$ & 4 & 10 & $54(84)$ & (91) & 101 & 87,04 \\
\hline RAZEM & 105 & 111 & 1044 & 1059 & 1040 & $-0,38$ \\
\hline
\end{tabular}

142 Statystyka dla wszystkich diecezji w 1853 r. została podana na podstawie: Список римскокатолических духовных лии...

143 Statystyka dla wszystkich diecezji w 1857 r. została podana na podstawie informacji z mapy Polikarpa Girsztowta zatytułowanej Mappa rzymsko-katolickich dyecezyj w Rossyi, wydanej w 1857 r., Z. Żuchowska, Polikarpa Girsztowta „Mapa rzymsko-katolickich diecezji w Rosji” wydana w 1857 roku, „Roczniki Humanistyczne” 34 (1986), z. 2, s. 567-574.

144 Podstawa źródłowa: tabela 4, do 1880 r. funkcjonował ponadto dekanat wielisko-newelski, który został włączony do witebskiego, Directorium horarum canonicarum et missarum pro archidioecesi Mohiloviensi in annum Domini 1857, Vilnae 1856, s. 104-131; Directorium... Mohyloviensi... $1914 \ldots$, s. 151-197; B. Kumor, Ustrój i organizacja..., s. 557, 680 (w 1858 r. - 165 parafii, w 1914 r. - 214 parafii).

145 Podstawa źródłowa: Directorium... Vilnensi... 1857..., s. 77-102; Directorium horarum canonicarum et missarum pro dioecesi Vilnensi in annum Domini 1912, Vilnae 1911, s. 17-83; Calendarium... Vilnensis... 1914..., s. 229-281; J. Skarbek, Organizacja parafialna $w$ diecezji wileńskiej..., s. 141; B. Kumor, Ustrój i organizacja..., s. 557, 672 (w 1856 r. - 301 parafii, w 1914 r. - 278 parafii).

146 Podstawa źródłowa: Directorium... Telsensi... 1859..., s. 89-117; Ordo... Samogitiensis... 1914..., s. 23-86; B. Kumor, Ustrój i organizacja..., s. 557, 674 (w 1853 r. - 213 parafii, w 1912 r. - 219 parafii).

147 Directorium horarum canonicarum et missarum pro dioecesi Luceoriensi in annum Domini 1856, Vilnae 1855, s. 79-97; Elenchus... Luceoriensis... 1914..., s. 118-134; B. Kumor, Ustrój i organizacja..., s. 557, 676 (w 1857 r. - 172 parafie, w 1914 r. - 161 parafii); Źródła do dziejów rozgraniczenia diecezji..., s. 56 .

148 Directorium officii divini dioecesis Camenecensis Podoliae in annum Domini 1856, Vilnae 1855, s. 99-103; Elenchus... Luceoriensis... 1914..., s. 134-143; B. Kumor, Ustrój i organizacja..., s. 557, 677 (w 1860 r. - 99 parafii, w 1914 r. - 98 parafii); Źródła do dziejów rozgraniczenia diecezji..., s. 5 .

149 Directorium officii divini ac missarum sanctarum pro dioecesi Minscensi in annum Domini 1856, Minsci 1855, s. 65-73; Directorium... Mohyloviensi... 1914..., s. 197-211; B. Kumor, Ustrój i organizacja..., s. 557, 675 (w 1880 r. - 51 parafii, w 1914 r. - 50 parafii).

150 Jako dekanat zostało potraktowane także wizytatorstwo kaukaskie i zakaukaskie. Odmienne stanowisko zajął Kumor, który nie uwzględnił wizytatorstwa w liczbie dekanatów diecezji tyraspolskiej w 1914 r., Directorium... Chersonensis... 1853..., s. 105-114; Directorium... Tiraspolensis... $1914 \ldots$, s. 24-68; B. Kumor, Ustrój i organizacja..., s. 557. W nawiasach podano sumarycznie liczbę kościołów obrządku ormiańskiego i łacińskiego. 


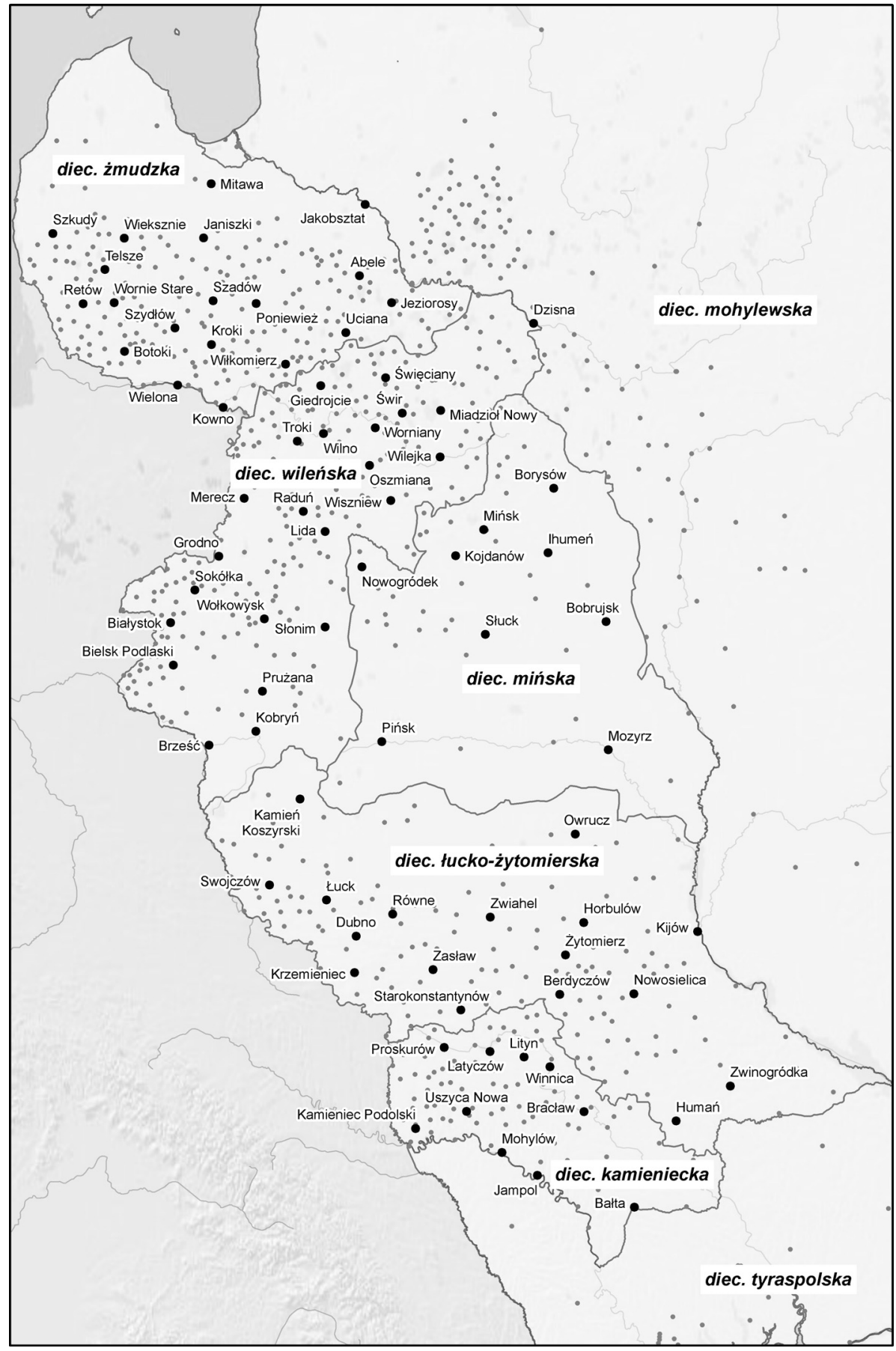

Rycina 3. Sieć parafialna oraz siedziby dekanatów w diecezjach: wileńskiej, żmudzkiej, lucko-żytomierskiej, mińskiej i kamienieckiej ok. 1914 r. Mapa bazowa: ESRI World Shaded Relief, http://services.arcgisonline.com/ArcGIS/services. 
Wyższe liczby podane przez Kumora (278 parafii) oraz Skarbka (281 parafii) prawdopodobnie są rezultatem uznania części kościołów nieparafialnych za parafialne ${ }^{151}$. $\mathrm{Z}$ tabeli 5 wynika, że $\mathrm{w}$ drugiej połowie XIX w. diecezja wileńska straciła ponad 40 kościołów parafialnych (ok. 15\%). Nie można wykluczyć, że część z nich przekształciła się w kaplice publiczne lub kościoły filialne, lecz zagadnienie to wymaga szczegółowych badań. Rozkład strat, związanych z działalnością władz państwowych po powstaniu styczniowym, nie był równomierny, na co zwrócił uwagę Skarbek. Najwięcej parafii (powyżej 30\%) zlikwidowano w dekanatach kobryńskim, brzeskim, słonimskim, wilejskim oraz prużańskim, co mogło łączyć się ze składem wyznaniowym tych terenów (znaczny odsetek ludności greckokatolickiej) ${ }^{152}$.

Zdecydowanie największy spadek liczby parafii na terenie metropolii mohylewskiej odnotowała w drugiej połowie XIX w. diecezja mińska (ok. 38\%). Jest to zjawisko dość trudne w szczegółowej analizie ze względu na zmiany struktury dekanalnej. Wydaje się, że na terenie całej diecezji swój stan posiadania, jeżeli chodzi o liczbę parafii, zachował tylko dekanat Bobrujsk. Względnie stabilna liczba parafii, biorąc pod uwagę skalę całej diecezji, utrzymywała się w biskupstwach żmudzkim, łucko-żytomierskim i kamienieckim. Z kolei największy wzrost, oprócz wspomnianych wschodnich i południowych części arcybiskupstwa, dotyczył nowo powstałej diecezji tyraspolskiej, która w ciągu półwiecza niemal podwoiła liczbę parafii łacińskich (struktury obrządku ormiańskiego nie były uwzględniane $\mathrm{w}$ analizie statystycznej). Liczbę parafii w diecezji tyraspolskiej ok. $1914 \mathrm{r}$. zaczerpnięto z bezpośrednich wzmianek dotyczących „kościołów parafialnych” (приходская церковь), pominięto natomiast domy modlitewne, filie, wikariaty, kaplice, nawet jeżeli posiadały okręgi duszpasterskie ${ }^{153}$.

\section{Podsumowanie}

Przedstawiona wyżej wstępna ocena rozwoju struktur dekanalnych oraz parafialnych metropolii mohylewskiej w latach 1783-1914 wprowadza istotne korekty do obowiązującego $w$ tym zakresie stanu wiedzy. Została oparta na literaturze przedmiotu oraz podstawowym materiale źródłowym przynoszącym sumaryczne zestawienia dekanatów i parafii, w pierwszym rzędzie na schematyzmach diecezjalnych. Nie ulega wątpliwości, że po uwzględnieniu pełniejszego materiału źródłowego, głównie akt wizytacyjnych, przedstawiony wyżej obraz ulegnie korektom, zaś zaprezentowana statystyka - weryfikacji.

Przed 1772 r. nie wytworzyła się na terenie Cesarstwa Rosyjskiego trwała organizacja terytorialna Kościoła katolickiego: funkcjonowały dwie prefektury: jedna

151 B. Kumor, Ustrój i organizacja..., s. 672; J. Skarbek, Organizacja parafialna $w$ diecezji wileńskiej..., s. 142.

152 J. Skarbek, Organizacja parafialna $w$ diecezji wileńskiej..., s. 138.

153 Directorium... Tiraspolensis... 1914..., s. 24-68. 
w Moskwie (z podprefekturą w Astrachaniu), druga w Petersburgu (z podprefekturami w Rydze i Saratowie) ${ }^{154}$. W wyniku rozbiorów Polski w granicach Rosji znalazły się 693 parafie, których funkcjonowanie ok. 1772 r. nie budzi większych wątpliwości. Cały ten obszar, jak również pozostałe tereny Cesarstwa znalazły się w granicach metropolii mohylewskiej utworzonej w $1783 \mathrm{r}$. Pierwsze wiarygodne dane statystyczne dla sieci parafialnej metropolii mohylewskiej dotyczą lat 1803-1804 (tabela 2) i wskazują na bardzo znaczny wzrost (o ok. 50\%) liczby parafii w porównaniu z 1772 r. Odnosi się on rzecz jasna nie tylko do terytoriów wchodzących w skład dawnej Rzeczypospolitej, ale całego Cesarstwa. Następne dekady charakteryzuje względna stabilność liczby parafii. W ciągu 110 lat przybyło na terenie metropolii jedynie 46 parafii, co oznacza wzrost o 4,6\%, a nie - jak podawał Kumor - o 30,4\%. Tak znaczne rozbieżności wynikają głównie z pominięcia w statystyce otwierającej (lata 1803-1804) kościołów parafialnych prowadzonych przez zgromadzenia zakonne oraz błędnej kwalifikacji kościołów parafialnych i filialnych podczas analiz ${ }^{155}$.

Obserwacja zmian w sieci parafialnej i dekanalnej na tak rozległym terytorium i w tak długiej perspektywie czasowej zmusza do wielu uproszczeń. Krytyczna ocena rozwoju sieci parafialnej wymaga pogłębionych studiów regionalnych oraz analitycznych opracowań monograficznych dla poszczególnych diecezji. Dopiero one mają szanse wskazać podstawowe czynniki warunkujące rozwój sieci parafialnej (rozwój osadnictwa, regulacje prawne, kasaty klasztorów i parafii). Na odrębną uwagę i dalsze badania zasługuje zagadnienie roli kościołów filialnych, kaplic publicznych i prywatnych oraz oratoriów. Ich liczba przewyższała dość znacznie liczbę parafii, co wpływało na charakter i sposób sprawowania opieki duszpasterskiej. Zjawisko kasat parafii wymaga dodatkowych studiów także w kontekście powstawania nowych świątyń i kaplic. Z rozwojem struktury organizacyjnej Kościoła katolickiego jest związane także duszpasterstwo parafialne prowadzone przez zakony.

\section{The Development of Parish and Deanery Structures of Mogilev Metropolis (1783-1918)}

\section{Abstract}

The incorporation of eastern territories of the Polish-Lithuanian Commonwealth together with the Latin dioceses and parishes of these areas into the Russian Empire eventuated in 1783 in the creation of the Mogilev metropolis - the biggest ecclesiastical province of the Catholic Church in the nineteenth century. Throughout the "long" nineteenth century, it evolved at all levels of the territorial organisation - from a parish to a diocese. These changes were determined by the political circumstances (for example, political borders, relations with the Holy See), internal transformations of the state (local governments, denomination policy regarding the Catholic Church and the Eastern Orthodox Church), and the situation within the Church itself.

154 J. Skarbek, Kościół katolicki w Rosji..., s. 7; Relationes status dioecesium in Magno Ducatu Lituaniae..., t. 2, s. 359.

155 B. Kumor, Ustrój i organizacja..., s. 681. 
The paper attempts to comprehensively characterise - quantitatively and spatially - the changes in the parish network in the Mogilev metropolis in the nineteenth century. Gathered source information, based on the cross-sectional sources including accounts and reports on the state of particular dioceses as well as the annual diocesan handbooks called Schematisms, served to assess the current body of scientific knowledge critically. The analysis is arranged in chronological and thematic order, and divided into three periods: 1772-1795, 1795-1847, 1847-1914. For each of them, the changes in the parishes network are described in the context of administrative units of the higher level: deaneries and dioceses (of Mogilev, Vilnius, Samogitia, Lutsk and Zhytomyr, Kamianets-Podilskyi, Minsk, Tiraspol).

The analysis shows that the number of Catholic parishes that can be found in the subject literature was often assessed without an in-depth examination of the source information, which led to incorrect conclusions. After a period of dynamic development of the parish network lasting until the first decade of the nineteenth century, it can be assumed that the number of parishes stabilised, increasing only slightly, across the entire ecclesiastical province. Within 110 years (1804-1914), the number of parishes in the metropolis increased by only 46, which means the growth of 4.6 percent, and not $30.4 \%$ as it was described previously by B. Kumor. The conducted analysis indicates that the changes in the territorial organisation of the Catholic Church in the Mogilev metropolis were disproportionate, and it makes it possible to identify the areas of the lower and higher dynamics of changes. Thus, it lays a foundation for further, more detailed, comparative research which will determine the main elements influencing the dynamics and shape of the observed changes (such as, for instance, legal regulations, settlement, and migrations, dissolutions, affiliated churches and oratories, the role of the religious orders).

\section{Развитие приходских и деканатских структур Могилёвской метрополии (1783-1918)}

\section{Аннотация}

Включение восточных территорий Речи Посполитой и латинских епархий и приходов, находившихся на ней, в Российскую империю привело в 1783 г. к созданию Могилевской церковной провинции - самого большого территориального образования католической церкви в XIX столетии. Во время «длинного» девятнадцатого века оно эволюционировало на всех уровнях территориальной организации - начиная с прихода, а кончая епархией. Эти изменения были определены политической обстановкой (напр. государственными границами, отношениями с Ватиканом), внутренними преобразованиями государства (местного правления, межконфессиональной политики по отношению к католической и православной церквам) а также самого положения католической церкви.

Статья пытается всестороннее охарактеризовать - в количественном и пространственном отношениях - перемены в сети приходов в Могилевской церковной провинции в девятнадцатом веке. Собранная информация, опирающаяся на поперечных источниках, включая сообщения и рапорты о состоянии отдельных епархий, а также епархиальные календари помогли критически оценить современные знания в этой области. Анализ проводился согласно хронологически-тематическому порядку, и разделен на три периода: 1772-1795, 1795-1847, 1847-1914. В каждом из них перемены в сети приходов были описаны в контексте высших административных единиц: деканатов и епархий (Могилёвской, Вильенской, Самогитской, Луцко-Житомирской, Каменец-Подольской, Минской, Тираспольской).

Анализ показывает, что число католических приходов, которое приводится в предметной литературе очень часто определено без глубинного исследования источниковой 
информации, что привело к неправильным заключениям. После периода динамического развития приходской сети, продолжавшегося до первого десятилетия XIX века, можно предположить, что число приходов стабилизировалось, только незначительно увеличилось во всей церковной провинции. За 110 лет (1804-1914) количество приходов на территории церковной провинции выросло всего на 46 , что означает рост в $4.6 \%$ а не в 30.4\% как это описывалось прежде у Б. Кумора. Проведенный анализ указывает на то, что изменения в территориальной организации католической церкви в Могилевской церковной провинции были непропорциональны, что позволило идентифицировать территории с меньшей и большей динамикой перемен. Следовательно, был открыт путь для дальнейшего, более детального, компаративного исследования, которое охарактеризует главные элементы, влиявшие на динамику и форму, наблюдавшихся изменений (напр. правовое урегулирование, расселение и миграции, упразднение, филиальные костелы и оратории, роль монашеских орденов).

\section{Bibliografia}

\section{Źródła}

Archivum Secretum Vaticanum

Congregatio Concilii, Relationes status: Luceoriensis 1788

Lietuvos Valstybės Istorijos Archyve

f. 604 , ap. 10 , b. 35

Akta wizytacji generalnej diecezji inflanckiej i kurlandzkiej czyli piltyńskiej z 1761 roku, wyd. S. Litak, Toruń 1998.

Calendarium pro clero dioecesis Vilnensis in annum Domini 1914, Vilnae 1913.

Chodźko I., Diecezja mińska około 1830 roku, t. 1: Struktury parafialne, wyd. M. Radwan, Lublin 1998 (Materiały do Dziejów Kościoła Katolickiego w Rzeczypospolitej i w Rosji, t. 5-6).

Die neuesten Zustände der katholishen Kirche beider Ritus in Poland und Russland seit Katharina II. bis auf unsere Tage. Mit einum Rückblick auf die Russische Kirche und ihrem Stellung zum heiligen Stuhle seit ihrem Entstehen bis auf Katharina II, wyd. A. Theiner, Augsburg 1841.

Dioeceses Luceoriensis et Żytomiriensis nec non ecclesiae per Podoliam anno Domini 1902, [Żytomiria b.d.w.].

Dioeceses Luceoriensis et Żytomiriensis nec non ecclesiae per Podoliam Anno 1894, [Żytomiria b.d.w.].

Directorium divini officii ac missarum ad usum dioecesis Luceoriensis pro anno bissextili 1808, Luceoriae [b.d.w.].

Directorium divini officii dioecesis Camenecensis Podoliae ac ecclesiarum in Bessarabia in annum Domini 1847 sede vacante editum, Vilnae 1847, http://www.petergen.com/bovkalo/sp/ camenec1847.html (dostęp: 15.02.2016).

Directorium divini officii et missarum pro archidioecesi Mohyloviensi nec non pro dioecesi Minscensi in annum Domini 1914, [b.m.d.w.].

Directorium horarum canonicarum et missarum ad usum utriusque cleri archidioecesis Mohileviensis, Petropoli 1848.

Directorium horarum canonicarum et missarum pro archidioecesi Mohiloviensi in annum Domini 1857, Vilnae 1856.

Directorium horarum canonicarum et missarum pro dioecesi Luceoriensi in annum Domini 1846, Vilnae 1845. 
Directorium horarum canonicarum et missarum pro dioecesi Luceoriensi in annum Domini 1856, Vilnae 1855.

Directorium horarum canonicarum et missarum pro dioecesi Telsensi in annum Domini 1843, Vilnae 1842.

Directorium horarum canonicarum et missarum pro dioecesi Telsensi seu Samogitiensi in annum Domini 1859, Vilnae 1858.

Directorium horarum canonicarum et missarum pro dioecesi Vilnensi in annum Domini 1821, Vilnae [b.d.w.].

Directorium horarum canonicarum et missarum pro dioecesi Vilnensi in annum Domini 1845, Vilnae 1844.

Directorium horarum canonicarum et missarum pro dioecesi Vilnensi in annum Domini 1846, Vilnae 1845.

Directorium horarum canonicarum et missarum pro dioecesi Vilnensi in annum Domini 1857, Vilnae 1856.

Directorium horarum canonicarum et missarum pro dioecesi Vilnensi in annum Domini 1912, Vilnae 1911.

Directorium horarum canonicarum et missarum pro dioecesi Vilnensi in annum Domini communem 1906, Vilnae 1905.

Directorium horarum canonicarum et sacrarum missarum ad usum dioecesis Tiraspolensis pro anno Domini 1914, Saratoviae 1913.

Directorium officii divini ac missarum ad usum dioecesis Luceoriensis pro anno Domini 1803, Luceoriae [b.d.w].

Directorium officii divini ac missarum ad usum dioecesis Luceoriensis pro anno Domini 1850, Vilnae 1849.

Directorium officii divini ac missarum dioecesis Camenecensis Podoliae in annum Christi 1817, Berdiczoviae [b.d.w.].

Directorium officii divini ac missarum sanctarum pro dioecesi Minscensi in annum Domini 1856, Minsci 1855.

Directorium officii divini dioecesis Camenecensis Podoliae ac ecclesiarum in Bessarabia in annum Domini 1845, Cameneci 1844.

Directorium officii divini dioecesis Camenecensis Podoliae ac ecclesiarum in Bessarabia in annum Domini 1846, Cameneci 1845.

Directorium officii divini dioecesis Camenecensis Podoliae in annum Domini 1856, Vilnae 1855.

Directorium officii divini et missarum generale pro utroque clero archidioecesis Mohyloviensis in annum Domini 1803, Polociae [b.d.w.].

Directorium officii divini et missarum generale pro utroque clero archidioecesis Mohiloviensis, Mohileviae 1820.

Directorium officii divini pro dioecesi Luceoriensis in annum Domini 1843, http://www.petergen. com/bovkalo/sp/luck1843.html (dostęp: 15.02.2015).

Directorium officii divini pro dioecesi Minscensi in annum Domini 1843, http://www.petergen. com/bovkalo/sp/minsk1843.html (dostęp: 16.02.2016).

Directorium officii divini pro dioecesi Tiraspolensi in annum Domini 1866, http://www.petergen. com/bovkalo/sp/tyraspol1866.html (dostęp: 8.03.2016).

Directorium seu ordo divini officii recitandi missaeque celebrandae ab utroque clero dioecesis Chersonensis in annum Domini 1853, Odessae [b.d.w.].

Elenchus cleri secularis dioeceseos Luceoriensis et Żytomiriensis ordine alphabetico confectus 1876, [Vilna b.d.w.].

Elenchus omnium ecclesiarum et universi cleri dioecesium Luceoriensis et Żytomiriensis nec non Camenecensis anno Domini 1914, [Żytomiria b.d.w.].

Fircks E. v., Neue Kurländische Güter-Chroniken, Mitau 1900. 
Girsztowt P., Mappa rzymsko-katolickich dyecezyj w Rossyi, St. Petersburg 1857.

Nonciature d'Arezzo 1802-1806, t. 1-2, wyd. M.J. de Journel, Città del Vaticano 1922 (Studi e testi, t. 168-169).

Ordo divini officii et missarum ad usum Samogitiensis seu Telsensis dioecesis pro anno Domini 1914, Seinis 1914.

Relationes status dioecesium in Magno Ducatu Lituaniae, t. 1-2, red. P. Rabikauskas, Roma 1971-1978 (Fontes Historiae Lituaniae, t. 1-2).

Słownik geograficzny Królestwa Polskiego i innych krajów słowiańskich, t. 1-15, red. F. Sulimierski, B. Chlebowski, W. Walewski, Warszawa 1880-1902.

Spisek łacińskiego duchowieństwa mohilewskiey archi-dyecezyi roku 1808, [b.m.d.w.].

Tetsch C.L., Curländische Kirchengeschichte, von dem Zustande dieser Provincial-Kirche, bis zum Ableben Gotthards ersten Herzogs zu Curland, nebst der gegenwärtigen äusserlichen kirchlichen Verfassung dieses Herzogthums, t. 1, Riga-Leipzig 1767.

Ukmerges dekanato vizitacija 1784 m., atlikta Vilniaus vyskupo Ignoto Jokūbo Masalskio parèdymu, wyd. S. Jegelevičius, Vilnius 2009 (Fontes Historiae Lituaniae, t. 8).

Źródła do dziejów rozgraniczenia diecezji łacińskich $w$ Cesarstwie Rosyjskim w połowie XIX wieku, t. 1, wyd. J. Skarbek, Lublin 2000.

Список римско-католических духовных лии, н учреждении, Санкт-Петербург 1853.

\section{Opracowania}

Bieńkowski L., Oświecenie i katastrofa rozbiorów (2. poł. XVIII w.), w: Chrześcijaństwo w Polsce. Zarys przemian 966-1979, red. J. Kłoczowski, Lublin 1992, s. 295-372 (Biblioteka Historii Społeczno-Religijnej Instytutu Geografii Historycznej Kościoła w Polsce, t. 7).

Encyklopedia wiedzy o jezuitach na ziemiach Polski i Litwy, 1564-1995, red. L. Grzebień, Kraków 1996.

Flaga J., Zakony męskie w Polsce w 1772 roku, t. 2, cz. 1: Duszpasterstwo, Lublin 1991 (Materiały do Atlasu Historycznego Chrześcijaństwa w Polsce, t. 8).

Gach P.P., Kasaty zakonów na ziemiach dawnej Rzeczypospolitej i Ślaska 1773-1914, Lublin 1984.

Kaliński T., Monografia parafii Narewka, [b.d.m.w.], http://www.narewka.archibial.pl/files/Historia_parafii_Narewka.pdf (dostęp: 30.03.2016).

Knapiński W., Mohilewska archidiecezja i prowincja, w: Encyklopedia kościelna, t. 14, red. M. Nowodworski, Warszawa 1881, s. 531-558.

Krahel T., Schematyzmy diecezji wileńskiej jako źródło historyczne, Lublin 1979.

Królik L., Organizacja diecezji łuckiej i brzeskiej od XVI do XVIII wieku, Lublin 1983.

Kumor B., Granice metropolii i diecezji polskich 966-1939, Lublin 1972.

Kumor B., Ustrój i organizacja Kościoła polskiego w okresie niewoli narodowej 1772-1918, Kraków 1980.

Kurczewski J., Biskupstwo wileńskie, Wilno 1912.

Librowski S., Katalog rubrycel i schematyzmów diecezji i zakonów historycznej Polski znajdujacych się w ksiegozbiorze podręcznym Archiwum Diecezjalnego we Włocławku: cz. 1. Rubrycele i schematyzmy diecezjalne, z. 3. Diecezja podlaska - diecezja warmińska, „Archiwa, Biblioteki i Muzea Kościelne” 25 (1972), s. 39-113.

Librowski S., Katalog rubrycel i schematyzmów diecezji i zakonów historycznej Polski znajdujacych się w księgozbiorze podręcznym Archiwum Diecezjalnego we Włocławku: cz. 1. Rubrycele $i$ schematyzmy diecezjalne, z. 4. Archidiecezja warszawska - diecezja żmudzka, „Archiwa, Biblioteki i Muzea Kościelne” 26 (1973), s. 89-197.

Litak S., Atlas Kościoła łacińskiego w Rzeczypospolitej Obojga Narodów w XVIII wieku, Lublin 2006. 
Litak S., Stosunki kościelne na ziemiach litewsko-ruskich w latach 1772-1815, w: Ziemie pótnocne Rzeczypospolitej polsko-litewskiej $w$ dobie rozbiorowej 1772-1815. Materiały $z$ konferencji międzynarodowej odbytej $w$ dniach 11-14 maja 1995 r. $w$ Toruniu, red. M. Biskup, Warszawa-Toruń 1996, s. 67-80.

Loret M., Kościół katolicki a Katarzyna II, 1772-1784, Kraków-Warszawa 1910 (Monografie w zakresie dziejów nowożytnych, t. 12).

Loret M., Kościół katolicki w początku panowania Aleksandra I (1801-1815), „Biblioteka Warszawska" 73 (1913).

Misius K., Šinkūnas R., Lietuvos kataliku bažnyčios. Žinynas, Vilnius 1993.

Prašmantaitė A., Žemaičiu vyskupas Juozapas Arnulfas Giedraitis, Vilnius 2000.

Schnurr J., Die Kirchen und das religiöse Leben der Russlanddeutschen. Katholischer Teil: Aus Vergangenheit und Gegenwart des Katholizismus in Rußland, Stuttgart 1980.

Skarbek J., Kościół katolicki w Rosji, [b.m.d.w.; mps].

Skarbek J., Kościół rzymskokatolicki na Białorusi i Litwie w XIX i początkach XX stulecia, „Sympozjum” (1999), nr 3 (1), s. 9-30.

Skarbek J., Organizacja parafialna $w$ diecezji wileńskiej $w$ latach 1772/3-1914, „Studia Teologiczne. Białystok, Drohiczyn, Łomża” 5-6 (1987-1988), s. 118-143.

Sułkowski W.A., Kartka $z$ dziejów kościoła katolickiego w Polsce rosyjskiej. Biskupstwo wileńskie, Kraków 1889.

Sułkowski W.A., Kartka z dziejów Kościoła katolickiego w Rosyi: Biskupstwo mińskie, Kraków 1889.

Szantyr S., Zbiór wiadomości o kościele i religii katolickiéj w Cesarstwie Rossyjskiem a szczególniéj w prowincyach od Polski przyłaczonych od czasu pierwszego rozbioru Polski aż do końca panowania cesarza Alexandra I. i początków panowania Mikołaja I, Poznań 1843.

Szot A., Dekanat białostocki w 1849 r., „Studia Teologiczne. Białystok, Drohiczyn, Łomża” 26 (2008), s. 487-500.

Wasilewski J., Arcybiskupi i administratorowie archidiecezji mohylowskiej, Pińsk 1930.

Wołonczewski M., Biskupstwo żmujdzkie, Kraków 1898.

Wołyniak [Giżycki Jan Marek], Zniesione kościoły i klasztory rzymsko-katolickie przez rząd rosyjski $w$ wieku XIX-tym $w$ diecezji łuckiej, żytomierskiej i kamienieckiej (gub. wołyńskiej, kijowskiej i podolskiej), „Nova Polonia Sacra” 1 (1928), s. 1-312.

Żuchowska Z., Polikarpa Girsztowta „Mapa rzymsko-katolickich diecezji w Rosji” wydana w 1857 roku, „Roczniki Humanistyczne” 34 (1986), z. 2, s. 567-574.

Кумор Б., Российский конкордат и создание Тираспольской епархии, http://catholichurch. ru/index.php/files/file/155-кумор-б-российский-конкордат-и-создание-тирасп/ (dostęp: 8.03.2016).

Лиценбергер О.А., Римско-католическая Церковь в России. История и правовое положение, Саратов 2001.

Лиценбергер О.А., Тираспольская епархия, w: Католическая энииклопедия, т. 4, Москва 2011, s. 1337-1342.

Bogumil Szady, profesor w Instytucie Historii KUL i Instytucie Historii PAN. Swoje zainteresowania badawcze koncentruje wokół geografii i kartografii historycznej oraz struktur organizacyjnych grup religijnych i wyznaniowych (szady@kul.lublin.pl).

Bogumil Szady, professor at the Institute of History of the John Paul II Catholic University of Lublin, and the Tadeusz Manteuffel Institute of History, Polish Academy of Sciences. His scientific interests focus on historical geography and cartography as well as the organizational structures of religious and denominational groups (szady@kul.lublin.pl). 